\title{
Oceanic Boundary Conditions for Jakobshavn Glacier. Part II: Provenance and Sources of Variability of Disko Bay and Ilulissat Icefjord Waters, 1990-2011*
}

\author{
CARL V. GLADISH ${ }^{+}$ \\ New York University Abu Dhabi, Abu Dhabi, United Arab Emirates \\ DAVID M. HOLLAND \\ New York University, New York, New York \\ CRAIG M. LEE \\ University of Washington, Seattle, Washington
}

(Manuscript received 11 March 2014, in final form 22 October 2014)

\begin{abstract}
Jakobshavn Glacier, west Greenland, has responded to temperature changes in Ilulissat Icefjord, into which it terminates. Basin waters in this fjord exchange with neighboring Disko Bay waters of a particular density at least once per year. This study determined the provenance of this isopycnic layer for 1990-2011 using hydrographic data from Cape Farewell to Baffin Bay. The warm Atlantic-origin core of the West Greenland Current never filled deep Disko Bay or entered the fjord basin because of bathymetric impediments on the west Greenland shelf. Instead, equal parts of Atlantic water and less-saline polar water filled the fjord basin and bathed Jakobshavn Glacier. The polar water fraction was often traceable to the East/West Greenland Current but sometimes to the colder Baffin Current. The huge annual temperature cycle on West Greenland Current isopycnals did not propagate into deep Disko Bay or the fjord basin because isopycnals over the west Greenland shelf were depressed during the warm autumn/winter phase of the cycle.

Ilulissat Icefjord basin waters were anomalously cool in summer 2010. This was not because of the record low NAO index winter of 2009/10 or atmospheric anomalies over Baffin Bay but, possibly, because of high freshwater flux through the Canadian Arctic and a weak West Greenland Current in early 2010. Together, this caused cold Baffin Current water to flood the west Greenland shelf. Subpolar gyre warming associated with the NAO anomaly in winter 2009/10 was more likely responsible for the record warm Disko Bay and Ilulissat Icefjord basin waters of 2011/12.
\end{abstract}

\section{Introduction}

In the late 1990s and early 2000s several outlet glaciers around Greenland began to rapidly thin in their lower reaches because of changes in their velocity fields, especially

\footnotetext{
* Supplemental information related to this paper is available at the Journals Online website: http://dx.doi.org/10.1175/JPO-D-140045.s1.

${ }^{+}$Current affiliation: Department of Earth, Atmospheric and Planetary Sciences, Massachusetts Institute of Technology, Cambridge, Massachusetts.
}

Corresponding author address: Carl Gladish, MIT Bldg 54-1423, 77 Massachusetts Ave., Cambridge MA, 02139.

E-mail: carlg@mit.edu the trio of major glaciers: Jakobshavn Glacier, Helheim Glacier, and Kangerdlugssuaq Glacier (Thomas et al. 2000, 2003; Krabill et al. 2004; Rignot and Kanagaratnam 2006; Howat et al. 2011). These glaciers all terminate in deep fjords connected by bathymetric troughs to the continental shelf break, and the observed accelerations have been attributed to changes near the termini leading to a reduction of the stresses tending to hold back ice flow (Thomas 2004; Howat et al. 2005; Joughin et al. 2004).

Jakobshavn Glacier (JG) terminates in the 750-800m-deep Ilulissat Icefjord (IIf) that opens into Disko Bay (DB) to the west (Fig. 1). Thomas et al. (2003) reported the onset of rapid thinning of Jakobshavn Glacier after 1997 and suggested that increased melting beneath the floating ice tongue still present at that time was related to the observed warming of the West 


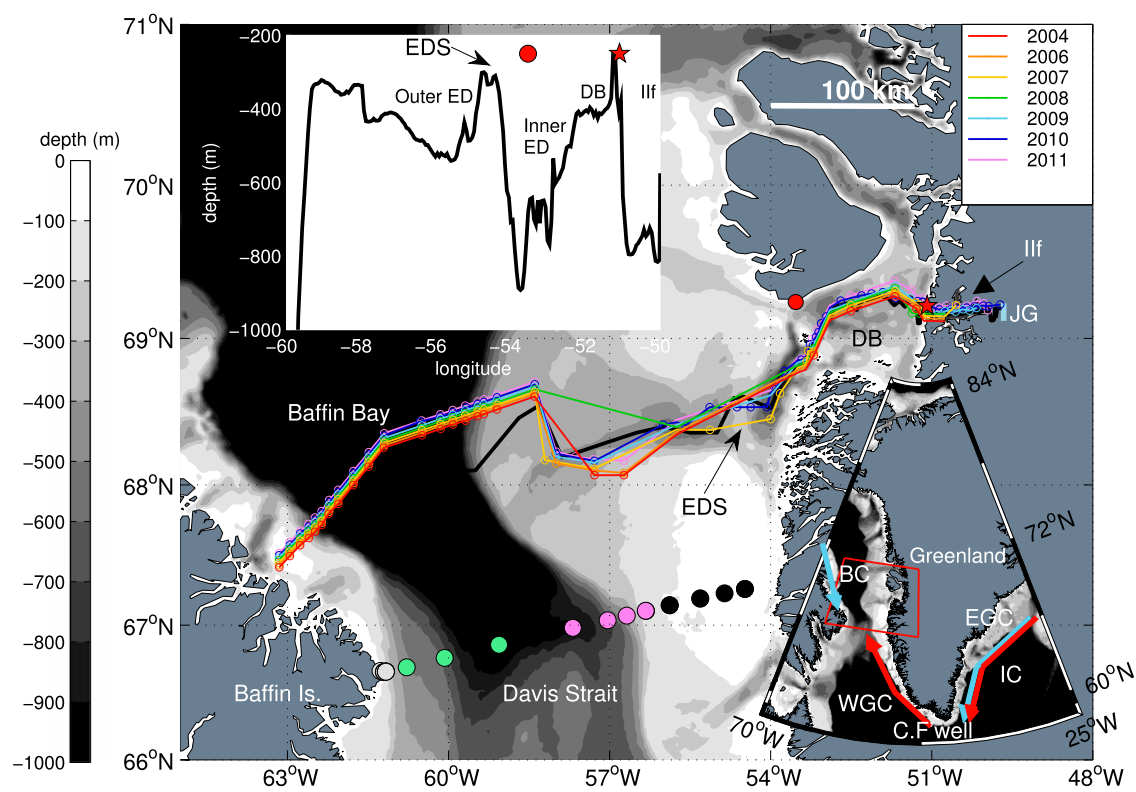

FIG. 1. Southern Baffin Bay and the west Greenland continental shelf west of DB, with bathymetry. The inset graph shows the depths along the ED (following the black path), which vary from $900 \mathrm{~m}$ in the inner ED south of Qeqertarsuaq (red circle) to $300 \mathrm{~m}$ at the EDS. Just south of Ilulissat (red star) is the entrance to IIf. A typical longitude of the terminus of JG is marked. Overlaid colored lines show the paths for the interpolated vertical sections in Fig. 3. Mooring locations just north of Davis Strait are shown. The inset map shows an overview of Greenland. The warm IC and WGC, along with the cooler EGC and BC are shown schematically.

Greenland Current (WGC) between 1994 and 1999. Holland et al. (2008) mapped the warming of subsurface waters along west Greenland (WG) in the late 1990s and traced its origin to a shift in large-scale winds over the North Atlantic. The warming of West Greenland Current waters was confirmed by closer analyses of available data for west Greenland (Myers et al. 2007, 2009) and in Disko Bay (Hansen et al. 2012; Myers and Ribergaard 2013). Motyka et al. (2011) combined glacier velocity and thickness data along with hydrographic data to quantify the ocean-triggering hypothesis. They concluded that the thinning from 1985 to 2001 was consistent with a $25 \%$ increase in basal melting under the ice tongue at Jakobshavn Glacier, which was in turn consistent with a $1^{\circ} \mathrm{C}$ warming of fjord waters.

More generally, waters originating in the subtropical Atlantic have been directly observed near the termini of the major glaciers undergoing change in recent years (Straneo et al. 2012). Greenland-wide remote sensing data and independent ocean reanalyses (Seale et al. 2011; Rignot et al. 2012) also support the hypothesis that ocean-warming triggered the nearly simultaneous accelerations of these glaciers. Although about half of the recent Greenland Ice Sheet mass loss has been attributed to increased outlet glacier discharge, many details are still unclear (Straneo and Heimbach 2013; Joughin et al.
2012). Here, we focus on Jakobshavn Glacier and observations from west Greenland waters. We aim to clarify how bathymetry and ocean currents in the surrounding region control how ocean heat is delivered to the vicinity of Jakobshavn Glacier.

In Part I of this work we focused on the fjord-scale dynamics related to temperature variability in Ilulissat Icefjord (Gladish et al. 2015). Hydrographic surveys in this fjord showed that the 500-m-thick basin layer is nearly homogeneous in temperature and potential density. The basin layer is a continuation of a certain isopycnic layer in Disko Bay, where the layer is much thinner and is found at depths equal to or somewhat shallower than the sill depth $(245 \mathrm{~m})$. Renewal of the basin occurs in as little as 1 month when subglacial freshwater discharged into the fjord provides sufficient buoyancy to eject basin waters over the sill at intermediate depth. In this way, interannual temperature variations in the basin track the interannual variations in Disko Bay within a certain potential density class (probably $27.20 \leq \sigma_{\theta} \leq 27.31 \mathrm{~kg} \mathrm{~m}^{-3}$, going back to at least the 1980s).

Here, we extend the scope of inquiry to west Greenland from Cape Farewell to Baffin Bay (Fig. 1). Using observations only, we attempt to determine the provenance and sources of variability of Disko Bay waters in this density class from 1990 to 2011. 
Two major currents flow toward the vicinity of the continental shelf west of Disko Bay: the West Greenland Current and Baffin Current (BC) (Fig. 1). The West Greenland Current has long been recognized as the source of the warmest subsurface waters in Disko Bay (Andersen 1981). In the long-term summer mean, the West Greenland Current is made up of low-salinity waters on the shelf and saltier waters below the surface layer over the shelf slope (Myers et al. 2009). The shelf portion of the West Greenland Current is primarily an extension of the freshwater-laden East Greenland Current (EGC) (Fig. 1) that carries waters of Arctic origin down the east coast of Greenland (Rudels et al. 2002). Next to the East Greenland Current is the warm Irminger Current, which, after rounding Cape Farewell, supplies warm and saline waters to the shelf slope part of the West Greenland Current. Low-salinity waters are also carried by the Baffin Current, which flows southward along the western side of Baffin Bay (Tang et al. 2004). The variability in Disko Bay with which we are concerned is generally traceable to changes involving the West Greenland Current and the Baffin Current.

In section 2, we present the datasets we used. The two main components were archived conductivity-temperaturedepth (CTD) profiles from summer and autumn between Cape Farewell and Baffin Bay from 1990 to 2011 and moorings deployed across Davis Strait (DS) from 2004 to 2011. Most of the CTD data have previously been presented (Myers et al. 2007, 2009; Myers and Ribergaard 2013; Hansen et al. 2012). The mooring data have also been recently analyzed with an emphasis on determining freshwater fluxes across Davis Strait (Curry and Lee 2011; Curry et al. 2014). Others have previously studied variability along the west Greenland shelf in Baffin Bay and in Disko Bay. Our contribution here is to account for interannual variability-as well as the lack of annual variability-in the density class of Disko Bay waters that fill Ilulissat Icefjord basin and constitute the major part of the oceanic thermal boundary conditions of Jakobshavn Glacier. With our observations inside Ilulissat Icefjord we were able to trace the origin of waters confronting Jakobshavn Glacier with more precision than previous studies. We found, for instance, that the warmest west Greenland waters mapped in Holland et al. (2008) did not reach Jakobshavn Glacier.

We first used the Davis Strait mooring data to classify all waters appearing in Davis Strait throughout the year (section 3). Using the archive of CTD profiles we were then able to account for specific summer by summer variability in Disko Bay/llulissat Icefjord waters between 1990 and 2011 (section 4b).

Curry et al. (2014) found that each year the subsurface temperature maximum of the West Greenland Current is warmest from November to January and coolest in April to June. The flow of the West Greenland Current across Davis Strait is also strongest in November to January (Tang et al. 2004; Cuny et al. 2005). However, in Gladish et al. (2015) we found a remarkable lack of subannual variability in Ilulissat Icefjord basin and deep Disko Bay compared to the annual autumn/winter pulse of warm water in the West Greenland Current. The next major aim of this paper, therefore, was to resolve this puzzle using the Davis Strait mooring data (section 4c).

The most conspicuous anomaly in Ilulissat Icefjord temperatures (observations covering 2009-13) occurred in 2010, when, for a single summer, temperatures in the fjord basin were as cool as they likely were in the 1980s (Gladish et al. 2015). In section 5, we investigate possible connections of this anomaly to large-scale and regional atmospheric anomalies. We find, however, that it is more likely that an anomalous pulse of freshwater entering the Baffin Current from the Canadian Arctic in early 2010 was the immediate cause.

\section{Observational data}

\section{a. Hydrographic data}

We downloaded 2300 CTD profiles from the ICES database ${ }^{1}$ covering southwest (SW) Greenland from 1990 until 2010. These profiles were collected mainly by the Greenland Institute of Natural Resources (GINR) and the Danish Meteorological Institute (DMI) and have been quality controlled by the DMI (Ribergaard 2013). We used an additional 326 CTD profiles collected by the GINR (from 1991, 1993, 1994, 2007, and 2011) not yet available from the ICES database (A. Rosing-Asvid 2012, personal communication; S. Rysgaard 2012, personal communication). Water properties in Disko Bay have been monitored by researchers of the Arctic Station on Disko Island for several decades (Hansen et al. 2012). We used 201 Arctic Station profiles collected since 1990. We also used CTD and expendable CTD (XCTD) profiles we collected in Disko Bay and Ilulissat Icefjord since 2007, previously presented in Gladish et al. (2015).

From 2004 to 2011, CTD sections in the vicinity of Davis Strait were occupied annually by University of Washington researchers (Curry and Lee 2011; Curry et al. 2014). We used 468 of these profiles, downloaded from the Arctic Observing Network archive. ${ }^{2}$ We also used data from the approximately 25 temperature, salinity, and pressure (no other tracer properties available) moorings

\footnotetext{
1 ocean.ices.dk/HydChem/

${ }^{2}$ www.aoncadis.org
} 

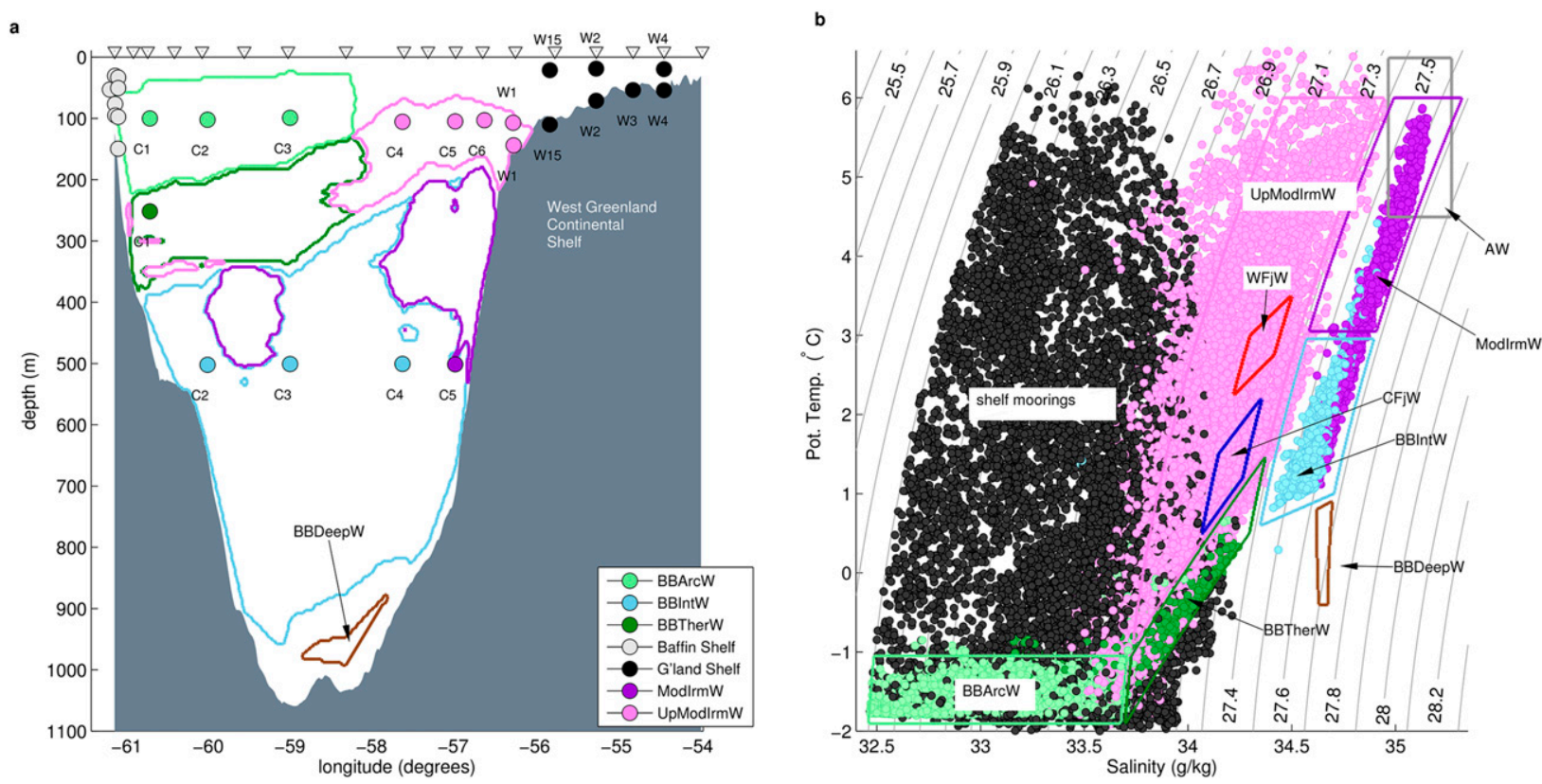

FIG. 2. (a) Circular markers indicate depths and longitudes of moorings deployed between 2004 and 2011 in Davis Strait. Moorings were collected into color-coded groups according to geographic proximity and the similarity of water properties sampled. Colored lines outline waters from the September 2004 CTD section along the Davis Strait mooring line (stations marked by triangles) according to the region of $\theta-S_{\mathrm{A}}$ space in which the data fall. (b) The $\theta-S_{\mathrm{A}}$ properties sampled by each mooring group (besides the Baffin Shelf group), color coded according to the legend in (a). Background contours are of potential density anomaly $\sigma_{\theta}$. The plot order was randomized so that colors do not obscure each other in a biased manner. Colored contours capture the $\theta-S_{\mathrm{A}}$ regions approximately traced out by various mooring groups, which we define and name in Table 2. No moorings sampled BBDeepW, but this water was detected in the CTD survey [(a)]. The $\theta-S_{\mathrm{A}}$ definitions of WFjW and CFjW and AW are also shown.

and 10 velocity moorings that have been deployed nearly continuously across Davis Strait as part of the same project. Depths and locations for these moorings varied slightly from year to year, but multiyear time series were assembled from disparate deployments for the stations shown at nominal locations and depths in Figs. 1 and 2a.

The raw mooring data contained spikes and intervals of unphysical salinities and densities that could be confounded with genuine variability, yet attempts to automatically remove these could suppress true variability. Our approach was based on the premise that temperature $T$ and Absolute Salinity $S_{\mathrm{A}}$ typically do not vary independently but fall approximately along a curve $T\left(S_{\mathrm{A}}\right)$ (see the appendix). After removing questionable samples, the mooring time series were bin averaged over 6-h intervals before subsequent processing.

As in Gladish et al. (2015), we used Absolute Salinity throughout this paper, as recommended by IOC et al. (2010). Profiles were interpolated and averaged into $2.0-\mathrm{m}$ vertical bins.

\section{b. Bathymetry}

Bathymetry was extracted from International Bathymetric Chart of the Arctic Ocean version 3 (IBCAO V3) (Jakobsson et al. 2012) at latitudes where it is available and otherwise from the 1-minute global gridded elevations/ bathymetry for the world (ETOPO1) dataset. ${ }^{3}$ The Egedesminde Dyb (ED), a 300- to 900-m trough cutting across the continental shelf from the shelf break into Disko Bay, is the main entrance for waters destined for Ilulissat Icefjord basin (Fig. 1). The shallowest part of the trough, southwest of Qeqertarsuaq, is an important barrier for deep water. We refer to this barrier as the Egedesminde Dyb Sill (EDS). The other important bathymetric impediment is the Iceberg Bank (i.e., sill) at the mouth of Ilulissat Icefjord (Fig. 1). Acoustic mapping over most of the crest and seaward apron of this sill (Schumann et al. 2012) shows that the fjord mouth is shallower than $200 \mathrm{~m}$ except in a region in the northern part of the mouth where there is a saddle point at $245-\mathrm{m}$ depth. Over the southern third of the mouth, the sill appears to be shallower than $100 \mathrm{~m}$.

\section{c. Meteorological data}

We used the ERA-Interim reanalysis product from the European Centre for Medium-Range Weather Forecasts (ECMWF) (Dee et al. 2011) to look for possible causal connections between surface atmospheric variables over

\footnotetext{
${ }^{3}$ www.ngdc.noaa.gov/mgg/global/global.html
} 
Davis Strait and Baffin Bay and ocean temperatures in Disko Bay and Ilulissat Icefjord. It is known that the ERA-Interim reanalysis lacks certain details of the coastal winds around Greenland, compared to the recently published higher-resolution Arctic System Reanalysis (ASR) (Bromwich et al. 2014, manuscript submitted to Quart. J. Roy. Meteor. Soc.). The ERA-Interim product has, however, been shown to better correlate with surface temperature, humidity, and wind speed observations than six other reanalysis products (not including the ASR) covering the Arctic (Lindsay et al. 2014). Surface fluxes over the Labrador Sea in an earlier version of the ECMWF analysis agreed to within observational uncertainties with shipbased observations (Renfrew et al. 2002).

\section{Fjord water provenance}

Hydrographic data collected in Ilulissat Icefjord from 2007 to 2013 show that the deep basin waters (east of the sill and west of the marine terminus of Jakobshavn Glacier) underwent interannual temperature variability of up to $1^{\circ} \mathrm{C}$ but with compensating salinity variability that left the potential density of the basin nearly constant (in the range $27.20 \leq \sigma_{\theta} \leq 27.31$ ) over all years (Gladish et al. 2015). Similarly, the density of sill depth waters in Disko Bay near Qeqertarsuaq have not changed significantly since at least 1980 , so we adopt the hypothesis that waters in the $27.20 \leq \sigma_{\theta} \leq 27.31$ range filled Ilulissat Icefjord basin and bathed Jakobshavn Glacier since at least 1980 . The constancy of density at $250 \mathrm{~m}$ reflects, presumably, stability in the nature of the densitydriven exchange between the west Greenland shelf and Disko Bay.

From here on, we understand variability of Ilulissat Icefjord basin waters to mean variability of Disko Bay waters in the range $27.20 \leq \sigma_{\theta} \leq 27.31$. A record of summer potential temperatures in Disko Bay in this category appears in Table 1. The years 1998, 1999, 2008, 2009, and 2011-13 were distinctly warmer than other years, falling into what we call the Warm Fjord Water (WFjW) category, while 1990, 1994, 2004, 2006, and 2010 were at least $1^{\circ} \mathrm{C}$ cooler than the warmest years, falling in the Cold Fjord Water (CFjW) category. Definitions for WFjW and CFjW appear in Table 2. We emphasize that in summer of 2010 , when $\mathrm{CFjW}$ was directly observed in Ilulissat Icefjord, the fjord basin waters were as cool as they likely were in years prior to the late 1990s retreat and acceleration of Jakobshavn Glacier.

\section{a. Regional water mass definitions from moorings}

To account for the variability of Disko Bay/Ilulissat Icefjord waters, we began by grouping the Davis Strait
TABLE 1. Mean potential temperature for water in Disko Bay in two different density categories in summer [June-August (JJA)]. Temperatures in the first density class cooler than $1.7^{\circ} \mathrm{C}$ (warmer than $2.7^{\circ} \mathrm{C}$ ) are shown in italics (bold) to highlight the years when Ilulissat Icefjord basin likely contained CFjW (WFjW), as defined in Table 2.

\begin{tabular}{lcc}
\hline \hline Year & $27.20 \leq \sigma_{\theta} \leq 27.31$ & $\sigma_{\theta}>27.31$ \\
\hline 1990 & 1.27 & 1.88 \\
$1991-93$ & - & - \\
1994 & 1.13 & 1.52 \\
$1995 / 96$ & - & - \\
1997 & 2.29 & 3.11 \\
1998 & $\mathbf{2 . 7 0}$ & 3.28 \\
1999 & $\mathbf{2 . 7 4}$ & 3.44 \\
2000 & 2.18 & 3.13 \\
2001 & 2.19 & 2.58 \\
2002 & 2.66 & 3.11 \\
2003 & 2.41 & 2.97 \\
2004 & 1.67 & 2.47 \\
2005 & 1.85 & 2.69 \\
2006 & 1.68 & 2.59 \\
2007 & 2.18 & 3.14 \\
2008 & $\mathbf{3 . 1 2}$ & 3.62 \\
2009 & $\mathbf{2 . 7 0}$ & 3.41 \\
2010 & 1.05 & 2.35 \\
2011 & $\mathbf{3 . 0 7}$ & 3.56 \\
2012 & $\mathbf{2 . 8 9}$ & 3.66 \\
2013 & $\mathbf{2 . 7 3}$ & 3.35 \\
\hline
\end{tabular}

moorings according to depth and location (Fig. 2a). For example, the moorings labeled $\mathrm{C} 1, \mathrm{C} 2$, and $\mathrm{C} 3$ near 100-m depth constitute the Baffin Bay Arctic Water (BBArcW) group. In Fig. 2b, the light green points from the BBArcW moorings fill out a compact region in the lower-left area of $\theta-S_{\mathrm{A}}$ space, which was then slightly idealized and used to define the BBArcW water mass, as recorded in Table 2. Similarly, we also defined Baffin Bay Intermediate Water (BBIntW), Baffin Bay Thermocline Water (BBTherW), Modified Irminger Water (ModIrmW), and upper-modified Irminger Water (UpModIrmW). Although no moorings sampled it, we also defined Baffin Bay Deep Water (BBDeepW) based on the autumn CTD surveys. Baffin shelf waters and Greenland shelf waters with $\sigma_{\theta}<27.0$ never overlap with Ilulissat Icefjord basin waters and were not categorized. Interpolated data from the September 2004 CTD section across the mooring line show a synoptic picture of the distribution of these water types (Fig. 2a).

\section{DISCUSSION OF WATER MASSES}

Notice that Fig. 2b can be regarded as a highly distorted vertical section across Davis Strait, rotated counterclockwise by $90^{\circ}$, since depth increases with density while temperature tends to increase to the east 
TABLE 2. Water mass definitions.

\begin{tabular}{|c|c|c|}
\hline Water mass & Definition & Comment \\
\hline WFjW & $\begin{array}{l}27.20 \leq \sigma_{\theta} \leq 27.31 \\
\theta \leq \frac{3.25-2.75}{27.31-27.20}\left(\sigma_{\theta}-27.20\right)+2.75 \\
\theta \geq \frac{2.75-2.25}{27.31-27.20}\left(\sigma_{\theta}-27.20\right)+2.25\end{array}$ & $\begin{array}{l}\text { Observed filling Ilulissat Icefjord basin summer } \\
2009 \text { and 2011-13. }\end{array}$ \\
\hline $\mathrm{CFjW}$ & $\begin{array}{l}27.20 \leq \sigma_{\theta} \leq 27.31 \\
\theta \leq \frac{2.2-1.5}{27.31-27.20}\left(\sigma_{\theta}-27.20\right)+1.5 \\
\theta \geq \frac{1.2-0.5}{27.31-27.20}\left(\sigma_{\theta}-27.20\right)+0.5\end{array}$ & Observed filling llulissat Icefjord basin summer 2010. \\
\hline BBArcW & $\begin{array}{l}26.0 \leq \sigma_{\theta} \leq 27.20 \\
-1.9 \leq \theta \leq-1.0\end{array}$ & Southward-flowing waters over Baffin slope. \\
\hline BBTherW & $\begin{array}{l}27.0 \leq \sigma_{\theta} \leq 27.4 \\
\theta \leq \frac{1.9-(-0.5)}{27.4-27.0}\left(\sigma_{\theta}-27.0\right)-0.5 \\
\theta \geq \frac{0.5-(-1.0)}{27.4-27.20}\left(\sigma_{\theta}-27.20\right)-1.0 \\
\theta \geq-1.0\end{array}$ & $\begin{array}{l}\text { Cool water typically underlying BBArcW and } \\
\text { overlying BBIntW. }\end{array}$ \\
\hline BBIntW & $\begin{array}{l}27.4 \leq \sigma_{\theta} \leq 27.675 \\
\theta \leq 3.0 \\
\theta \geq \frac{3.0-0.5}{27.675-27.4}\left(\sigma_{\theta}-27.4\right)+0.5\end{array}$ & Winter-cooled water at middepths of Baffin Bay. \\
\hline BBDeepW & $\begin{array}{l}\theta \geq-0.4 \\
\theta \geq-16.0 \sigma_{\theta}+442.8 \\
\theta \geq 2.0 \sigma_{\theta}+54.45 \\
\theta \geq-23.6364 \sigma_{\theta}+655.0 .36\end{array}$ & Dense waters below Davis Strait sill depth. \\
\hline UpModIrmW & $\begin{array}{l}27.0 \leq \sigma_{\theta} \leq 27.4 \\
\theta \leq 6.0 \\
\theta \geq \frac{2.0-(-0.5)}{27.4-27.0}\left(\sigma_{\theta}-27.0\right)-0.5\end{array}$ & $\begin{array}{l}\text { Intermediate depth waters over the west Greenland } \\
\text { continental slope. }\end{array}$ \\
\hline ModIrmW & $\begin{array}{l}27.4 \leq \sigma_{\theta} \leq 27.675 \\
3.0 \leq \theta \leq 6.0\end{array}$ & Deep water over the west Greenland slope. \\
\hline PWS & $\begin{array}{l}\sigma_{\theta} \leq 27.7 \\
\theta \leq 0^{\circ} \mathrm{C}\end{array}$ & $\begin{array}{l}\text { Cold waters in the East Greenland Current } \\
\text { (Rudels et al. 2002). }\end{array}$ \\
\hline AW & $\begin{array}{l}4.5 \leq \theta \leq 6.5 \\
34.8 \leq S_{p} \leq 35.1(\mathrm{psu})\end{array}$ & Definition from Sutherland and Pickart (2008). \\
\hline
\end{tabular}

in Davis Strait. BBDeepW, which exhibited little variability, occupied a tiny region of $\theta-S_{\mathrm{A}}$ space and a small region of physical space across Davis Strait. (BBDeepW fills all of Baffin Bay below 1000-m depth.)

Adjacent to this in $\theta-S_{\mathrm{A}}$ space and in physical space, BBIntW occupied a small region in $\theta-S_{\mathrm{A}}$ space but a huge fraction of the area of the mooring line CTD section (Fig. 2a). Our definition of BBIntW is essentially the same as that of Tang et al. (2004), who refer to it as west Greenland Intermediate Water. They found that most of Baffin Bay from 300- to 800-m depth is filled with this water type, which enters Baffin Bay as warm West Greenland Current water and is gradually cooled as it circulates cyclonically around the bay.

What we here call BBArcW is called cold intermediate layer (CIL) water by Cuny et al. (2005), who found that it enters Baffin Bay from the Canadian Arctic Archipelago near Lancaster Sound. This water mass contains the subsurface temperature minimum within the low-salinity and cold Baffin Current (Tang et al. 2004).

Underlying the near-freezing BBArcW and overlying the warmer BBIntW is BBTherW, which falls along a line in $\theta-S_{\mathrm{A}}$ space (Fig. 2b). Since this is a thin layer with a large thermal gradient, it is sensible to call it thermocline water and to attribute its characteristics to mixing between the overlying BBArcW and the underlying BBIntW. Note that on each $\sigma_{\theta}$ contour between 27.0 and 27.4, BBTherW was the coldest water in Baffin Bay. Curry and Lee (2011) refer to all the water below BBArcW as transition water ( $\mathrm{TrW}$ ) and therefore show TrW as filling Davis Strait to the seafloor. 
What we here call ModIrmW is a modified version of Irminger Current (IC) waters east of Cape Farewell. The Irminger Current flows southwest over the southeast (SE) Greenland shelf slope alongside the low-salinity East Greenland Current, forming a temperature and density front approximately above the shelf break. On the warm side of this front, Irminger Current waters have characteristic potential density $\sigma_{\theta}=27.5-27.6$, potential temperature $5^{\circ}-6^{\circ} \mathrm{C}$, and salinity of 35.0 35.05 on the practical salinity scale (Våge et al. 2011). These properties, already somewhat modified from "pure" Irminger water over the Reykjanes Ridge, are squarely within the definition of Atlantic Water (AW) given in Sutherland and Pickart (2008) in the context of studying the East Greenland Current. The definition of AW from Sutherland and Pickart (2008) overlaps with the warmer end of our ModIrmW (Fig. 2b). These warm waters flow around Cape Farewell and then flow north over the southwest Greenland shelf slope, suffering some modification because of mixing with adjacent Labrador Seawater (Bacon et al. 2002; Cuny et al. 2005; Myers et al. 2009). Figure 2b shows, however, that ModIrmW was too dense to ever gain entry to Ilulissat Icefjord (i.e., it is denser than WFjW and CFjW and has not been observed in Ilulissat Icefjord).

It is UpModIrmW that contains $\mathrm{WFjW}$ and $\mathrm{CFjW}$ in $\theta-S_{\mathrm{A}}$ space. In September 2004, for instance, UpModIrmW flowed alongside the upper shelf slope between depths of about 100 to $200 \mathrm{~m}$ (Fig. 2a). In summer and autumn CTD surveys, UpModIrmW was found roughly midway along a mixing line between the temperature maximum in the West Greenland Current and the less-saline waters on the Greenland shelf. Therefore, not only the waters above the sill depth but also the waters filling Ilulissat Icefjord basin contained a significant fraction of polar water (i.e., waters of Arctic origin). Myers and Ribergaard (2013) proposed that temperature variability of low-salinity polar water could impact the thermal boundary conditions of Jakobshavn Glacier. We have confirmed that this is true to an even greater extent than those authors perhaps meant to suggest.

\section{b. Spatial distribution of water masses, Baffin Bay to Disko Bay}

Using CTD data described in section 2, we assembled vertical sections of potential temperature from Baffin Bay to Jakobshavn Glacier approximately following the path of Egedesminde Dyb (Fig. 1) for 2004 and 2006-11 (Figs. 3a-g). These sections are not truly synoptic since stations were occupied at various times from June until mid-October.
In these sections, Ilulissat Icefjord and Disko Bay (down to about $500 \mathrm{~m}$ ) were filled with UpModIrmW. As Andersen (1981) already found for years up to 1975, the warmest West Greenland Current waters (here ModIrmW) do not enter Disko Bay in significant amounts, although we found that ModIrmW generally flows along the Egedesminde Dyb up to the Egedesminde Dyb Sill (visible in 2007 and 2010). In years where ModIrmW was also found east of the Egedesminde Dyb Sill (2006, 2008, 2009, and 2011), the upper vertical limit of this water type was considerably deeper than the Egedesminde Dyb Sill. Being denser than UpModIrmW, ModIrmW ought to eventually fill up Disko Bay east of the Egedesminde Dyb Sill and eventually lap against the sill at the fjord mouth, possibly entering the fjord itself. The fact that this did not occur suggests that the flow of ModIrmW over the Egedesminde Dyb Sill was severely restricted. Any such flow was either intermittent or else ModIrmW was significantly mixed with cooler and lighter overlying water as it entered Disko Bay. In either case, the Egedesminde Dyb Sill appears to have prevented ModIrmW from filling Disko Bay up to depths that would give this warmer water potential access to Ilulissat Icefjord. The other water masses of Baffin Bay did not occupy the Greenland shelf west of Disko Bay in summer, although the intermingling of contours of UpModIrmW and BBTherW in Baffin Bay suggests that isopycnic mixing between these waters occurred to some extent.

For 2004 and 2006, no data in Ilulissat Icefjord are available, but we infer from Disko Bay profiles that Ilulissat Icefjord basin was filled with CFjW (Table 1). This is reflected in the mostly continuous stripe of $\mathrm{CFjW}$ in the $\theta$ sections from the shelf break to Ilulissat. In 2007, Ilulissat Icefjord waters were intermediate between $\mathrm{CFjW}$ and $\mathrm{WFjW}$, and this is reflected in the absence of WFjW or CFjW in central to eastern Disko Bay and their patchy presence toward the shelf break. In 2008, disparate CTD casts in Disko Bay generally show the presence of WFjW. In 2009, 2010, and 2011, water filling Ilulissat Icefjord basin is seen as a mostly continuous layer across Disko Bay but in no years is the layer of CFjW or WFjW definitely continuous all the way to the shelf break. This is likely because of the separations in time between the various CTD casts, with those in Baffin Bay always from September to October, those from the shelf and Disko Bay typically in mid-June to mid-July, and those inside Ilulissat Icefjord in July or August.

\section{DisCUSSION OF POLAR WATER}

We have shown that Ilulissat Icefjord basin waters are always a subset of UpModIrmW, which is always less saline than AW. The low-salinity fraction of 


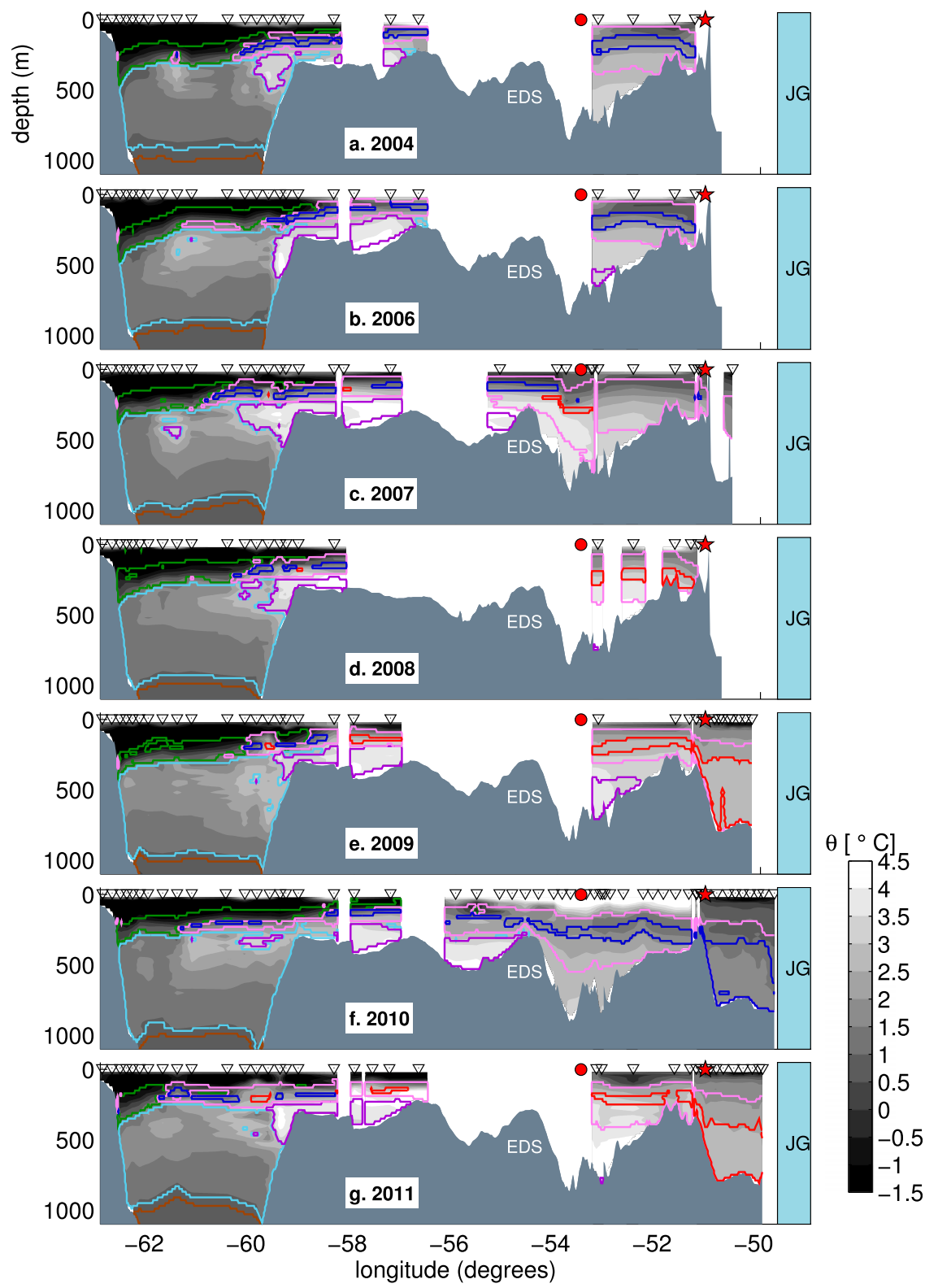

FIG. 3. Sections of potential temperature from Baffin Bay to Ilulissat Icefjord interpolated between XCTD/CTD stations (marked by triangles) along the paths in Fig. 1. Instead of interpolating between widely separated stations (in space or time), white space is shown (significant spaces being $\Delta t \geq 2$ days and $\Delta x \geq 30 \mathrm{~km}, \Delta t \geq 20$ days, or $\Delta x \geq 100 \mathrm{~km}$ ). A fixed position of Jakobshavn Glacier (JG) terminus (a typical position from 2009 to 2011) is shown each year. Dark gray shading shows IBCAO v3 bathymetry sampled along the section, except east of the fjord mouth (marked by a red star) where cast bottoms are allowed to override the IBCAO bathymetry. Qeqertarsuaq and Ilulissat are marked by a red circle and red star, respectively. EDS, southwest of Qeqertarsuaq, is visible at $54.5^{\circ} \mathrm{W}$ in each panel. Other bathymetric impediments west of the Egedesminde Dyb Sill are only apparent since the interpolation paths do not exactly follow the trough. Water masses as defined in Table 2 are enclosed by thin colored lines according to the color scheme in Fig. 2 (except BBArcW, which is omitted for the sake of clarity and AW, none of which is present). 
UpModIrmW can reach Disko Bay by two possible pathways: via the West Greenland Current or via the Baffin Current. Both sources are of Arctic origin, but the low-salinity West Greenland Current waters have traveled a much longer path around Greenland and are significantly warmed. Because of its multiple sources, widely varying properties, and eventual role in forming fjord water, we delve next into an analysis of polar water.

\section{(i) Polar Water north of Denmark Strait}

Between Fram Strait and Denmark Strait, waters on the northeast Greenland continental shelf are above and to the west of the $\sigma_{\theta}=27.9$ isopycnal, which intersects the seafloor at about the shelf break [see CTD sections I, II, and III of Rudels et al. (2002) and CTD section 5 of Sutherland and Pickart (2008)]. Rudels et al. (2002) classify waters lighter than $\sigma_{\theta}=27.7$ as Polar Surface Water (PSW) if $\theta<0^{\circ} \mathrm{C}$ or warm Polar Surface Water (PSWw) if $\theta>0^{\circ} \mathrm{C}$. In this region, PSWw is formed mainly by sea ice melting on top of warm Atlantic surface water and is found seaward of the shelf break. The shelf itself is completely occupied by PSW.

We point out that despite the fact that polar waters make up the low-density upper layer in many Greenland glacial fjords (Straneo et al. 2012), PSW on the east Greenland shelf can be very dense compared to the densities of the subpolar gyre and Baffin Bay with which we are primarily concerned. After all, in the Irminger basin east of Cape Farewell, no water with $\sigma_{\theta}=27.9$ is found at any depth, and the $\sigma_{\theta}=27.7$ isopycnal intersects the east Greenland shelf slope at about 750-m depth (Våge et al. 2011). In Baffin Bay, only BBDeepW is as dense as $\sigma_{\theta}=27.7$.

North of Denmark Strait, the $\sigma_{\theta}=27.9$ isopycnal slopes upward east of the shelf break, defining a front between the PSW and the even denser near-surface waters of the Greenland and Iceland Seas. The density front this forms is associated with the strong southward East Greenland Current (Rudels et al. 2002).

\section{(ii) Polar Water south of Denmark Strait}

South of Denmark Strait the surface waters of the Irminger Sea are much less dense than those north of Iceland, and the isopycnals over the Greenland shelf break begin to curve downward. As the densest shelf waters drain down the continental slope, they form the fast equatorward East Greenland Spill Jet and vigorous horizontal exchange between shelf and Irminger Sea waters occurs (Pickart et al. 2005). Such mixing explains how PSW with $\sigma_{\theta} \geq 27.4$ is completely eliminated from the East Greenland Current as it flows from the north to the south of Denmark Strait (Sutherland and Pickart 2008;
Rudels et al. 2002). As they are mixed, these dense PSW parcels appear to migrate about halfway toward pure AW along (diapycnal) mixing lines in $\theta-S$ space. The temperature minimum over the east Greenland shelf/ slope therefore becomes progressively warmer and less dense, while the eroding density front retreats toward the coast (see sections 5, 4, and 2 of Sutherland and Pickart 2008). We suggest that the unmodified PSW south of Denmark Strait, much less dense and confined by a front near the coast, constitutes the headwaters of the East Greenland Coastal Current. This is complementary to the idea that this current is made up of runoff from melting glaciers (Bacon et al. 2002).

Sutherland and Pickart (2008) showed that, in any case, the PSW that remained south of Denmark Strait was gradually modified until no water cooler than $2.0^{\circ} \mathrm{C}$ with $\sigma_{\theta} \geq 27.0$ remained on the shelf at Cape Farewell in July 2004. They suggest this modification was because of surface heat fluxes and melting sea ice. Their Fig. 2, however, shows that vertical temperature gradients near the surface were flat south of Denmark Strait in July/August 2004, so heating of PSW from above seems unlikely. An alternative is that the progressive warming of the entire East Greenland/Irminger Current mixing line (for $\sigma_{\theta} \geq 27.0$ ) was because of compounding diapycnal mixing of East Greenland Current waters with the effectively infinite reservoir of Irminger Current water.

As waters of the East Greenland/Irminger Current round Cape Farewell, they become the West Greenland Current. Myers et al. (2009) showed that West Greenland Current waters do not exhibit either a clear warming or cooling tendency as they progress north. The temporal variability at each cross-shelf summer CTD section obscures any systematic spatial trend, except that the northern section (Maniitsoq, just south of Davis Strait) always lacks the very warmest and densest waters seen in the southern sections.

To summarize, the East/West Greenland Current pathway delivers polar water (or polar-influenced water) that ought to be called "cool" rather than "cold" since it is at least $3^{\circ} \mathrm{C}$ warmer than PSW when it begins its journey south in the East Greenland Current. It is not clear if colder East Greenland Coastal Current waters are ever carried unmodified all the way to Davis Strait.

The second source of polar water is the Baffin Current, which carries cold $\left(\theta \leq-1.5^{\circ} \mathrm{C}\right)$ and fresh $\left(S_{\mathrm{A}} \leq\right.$ $\left.33.65 \mathrm{~g} \mathrm{~kg}^{-1}\right)$ water southward in a broad current covering west and central Baffin Bay (Cuny et al. 2005). The thermocline waters directly below this (i.e., BBTherW, in our classification), which also tend to flow southward, should also be considered polar-influenced water. 
a WG1-151

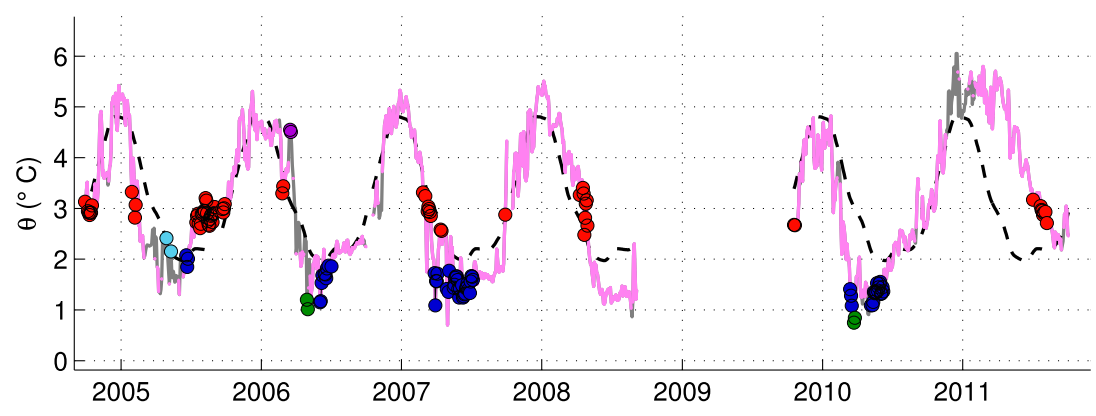

b

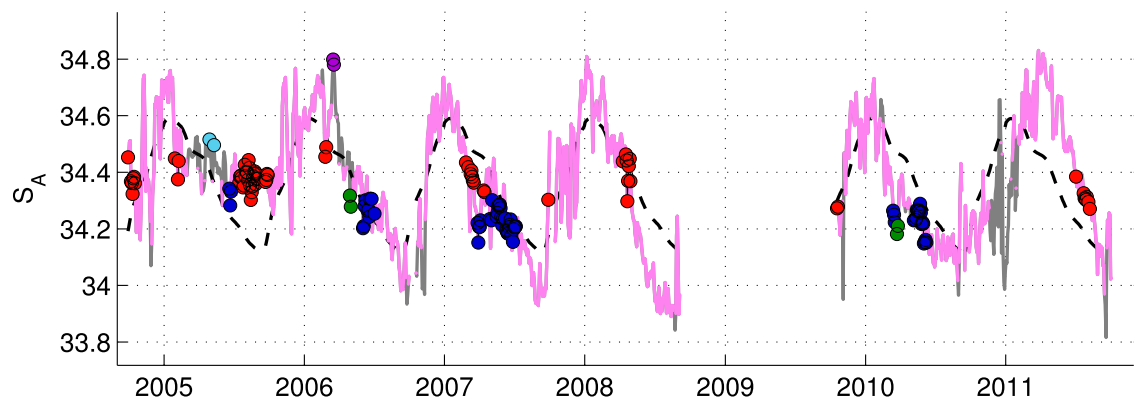

c

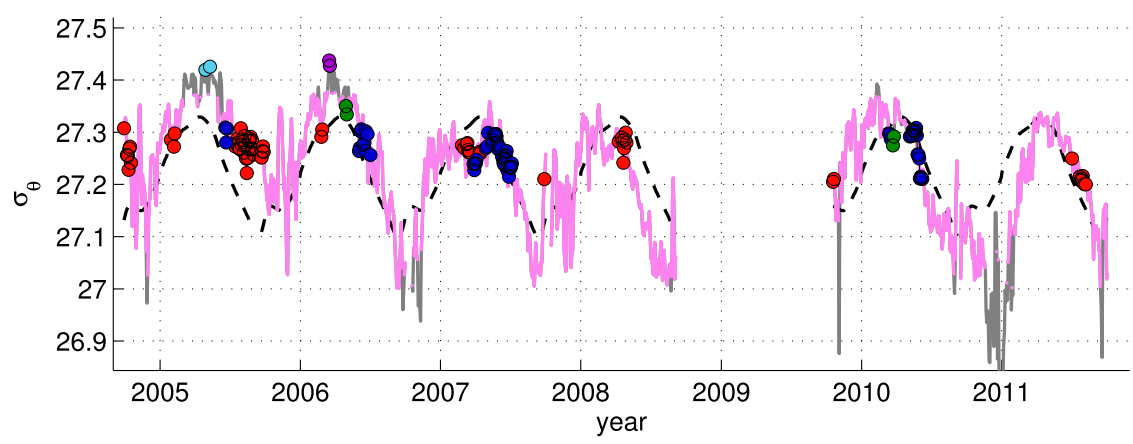

FIG. 4. Time series of water properties from mooring $\mathrm{W} 1$ at $151 \mathrm{~m}$, averaged over 2-day bins. (a) The main curve shows potential temperature $\theta$ and is gray by default. However, when UpModIrmW is present, the curve is pink, and when BBTherW, BBIntW, CFjW, WFjW, or ModIrmW are present colored dots are shown (colors as in Fig. 2). The dashed black line is the mean annual cycle (2004-11). (b),(c) As in (a), but for Absolute Salinity $S_{\mathrm{A}}$ and potential density $\sigma_{\theta}$.

\section{Sources of Disko Bay/llulissat Icefjord variability}

\section{a. Evidence from mooring WG1-151}

To introduce the questions we are concerned with in this section, we show the time series from mooring WG1-151 (Fig. 4). This mooring monitored waters over the west Greenland shelf break (151-m depth) just north of Davis Strait and just south of the entrance of Egedesminde Dyb from 2004 to 2011 (see Figs. 1 and 2a).

Mooring WG1-151 was usually immersed in UpModIrmW and detected a $3^{\circ}-4^{\circ} \mathrm{C}$ annual variation in temperature, $0.5-0.8 \mathrm{~g} \mathrm{~kg}^{-1}$ annual variation in salinity, and
$0.3-0.5 \mathrm{~kg} \mathrm{~m}^{-3}$ annual variation in density. Appearances of $\mathrm{WFjW}$ and $\mathrm{CFjW}$ were fleeting since the temperature and density swept through $\theta-S_{\mathrm{A}}$ space quickly each year. The presence of WFjW in the first few months of a year did not necessarily precede a summer in which WFjW was detected in Disko Bay (i.e., 2005-07). However, $\mathrm{CFjW}$ was present during spring in precisely the four coolest years in Disko Bay: 2005-07 and 2010. During the two coldest years, 2006 and 2010 (Table 1), this mooring was flooded by BBTherW in the spring for brief periods (green markers, Fig. 4). As a result, $\theta$ dropped by $2.5^{\circ} \mathrm{C}$ in the last two weeks of March 2006, and $\theta$ dropped by $3^{\circ} \mathrm{C}$ in four weeks beginning in mid-February 2010 . 


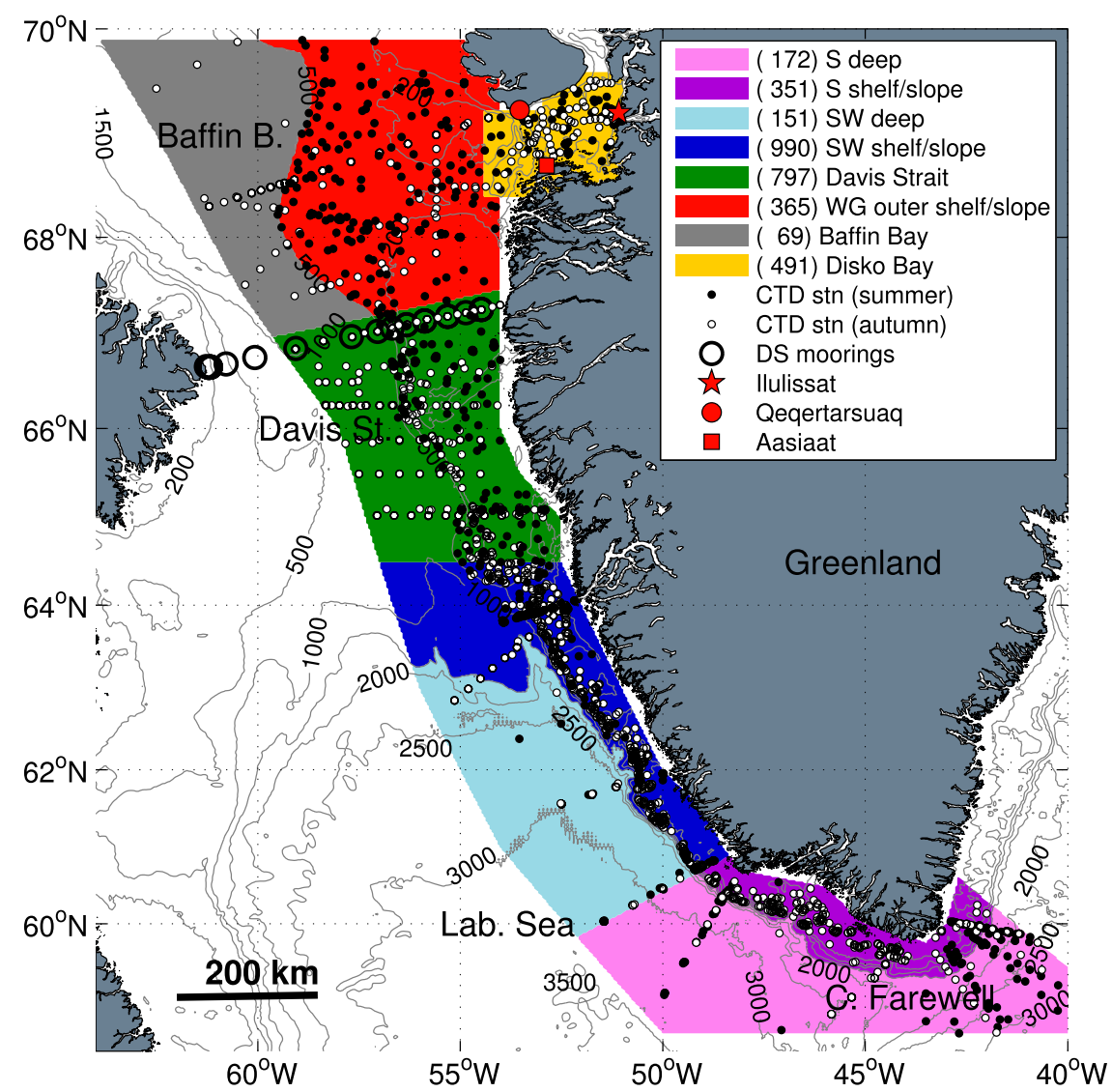

FIG. 5. Regions used to group CTD and mooring stations. The S deep and SW deep are bounded by the 1500-m isobaths; S shelf/slope and SW shelf/slope are bounded by the $1500-\mathrm{m}$ isobath and a line that skirts past any fjords along the coast. The Davis Strait region covers Davis Strait up to just north of the mooring line. Baffin Bay and the WG outer shelf/slope west of Disko Bay are separated by the 500-m isobath. Disko Bay includes stations east of the Egedesminde Dyb Sill but outside Ilulissat Icefjord.

Although BBArcW (not necessarily from the Baffin Current) did appear on the west Greenland shelf each winter at moorings east of WG1-151, slightly denser BBTherW only appeared at shelf moorings in 2006 and 2010. Also, the four moorings at 105-m depth above and west of WG1-151 suggest that the BBTherW in 2010 (and possibly 2006, but data are lacking) originated from the west (supplemental information). This is evidence that the cool fjord temperatures in 2010 and possibly 2006 were because of an incursion of BBTherW from the Baffin Current onto the west Greenland shelf break, which would likely have mixed with slightly warmer UpModIrmW to produce the $\mathrm{CFjW}$ that filled Disko Bay/Ilulissat Icefjord later in the summer.

Mooring WG1-151 introduces several new questions, however, which we address below using a larger set of data. First, WG1-151 shows that UpModIrmW at the west Greenland shelf break in Davis Strait runs over a much wider range of temperatures each year than is observed in Disko Bay/Ilulissat Icefjord (Gladish et al. 2015). It is still unclear why the warmest UpModIrmW (over $5^{\circ} \mathrm{C}$ ) in midwinter did not enter Ilulissat Icefjord. Second, from WG1-151 alone it is unclear why WFjW was sometimes observed in the West Greenland Current early in a given year without it appearing in Disko Bay/ Ilulissat Icefjord later in the summer (2005-07). Finally, the fundamental reason(s) for the cold anomalies (especially 2006 and 2010) is yet to be explained.

\section{b. Interannual variability along west Greenland, 1990-2011}

\section{1) EVIDENCE FROM CTD PROFILES}

We next categorized CTD profiles from Cape Farewell to Baffin Bay by region, year (1990-2011), and season. The seasons were extended summer [May-August (MJJA)] and autumn [September-November (SON)]. The regions are shown in Fig. 5. We occasionally refer to 

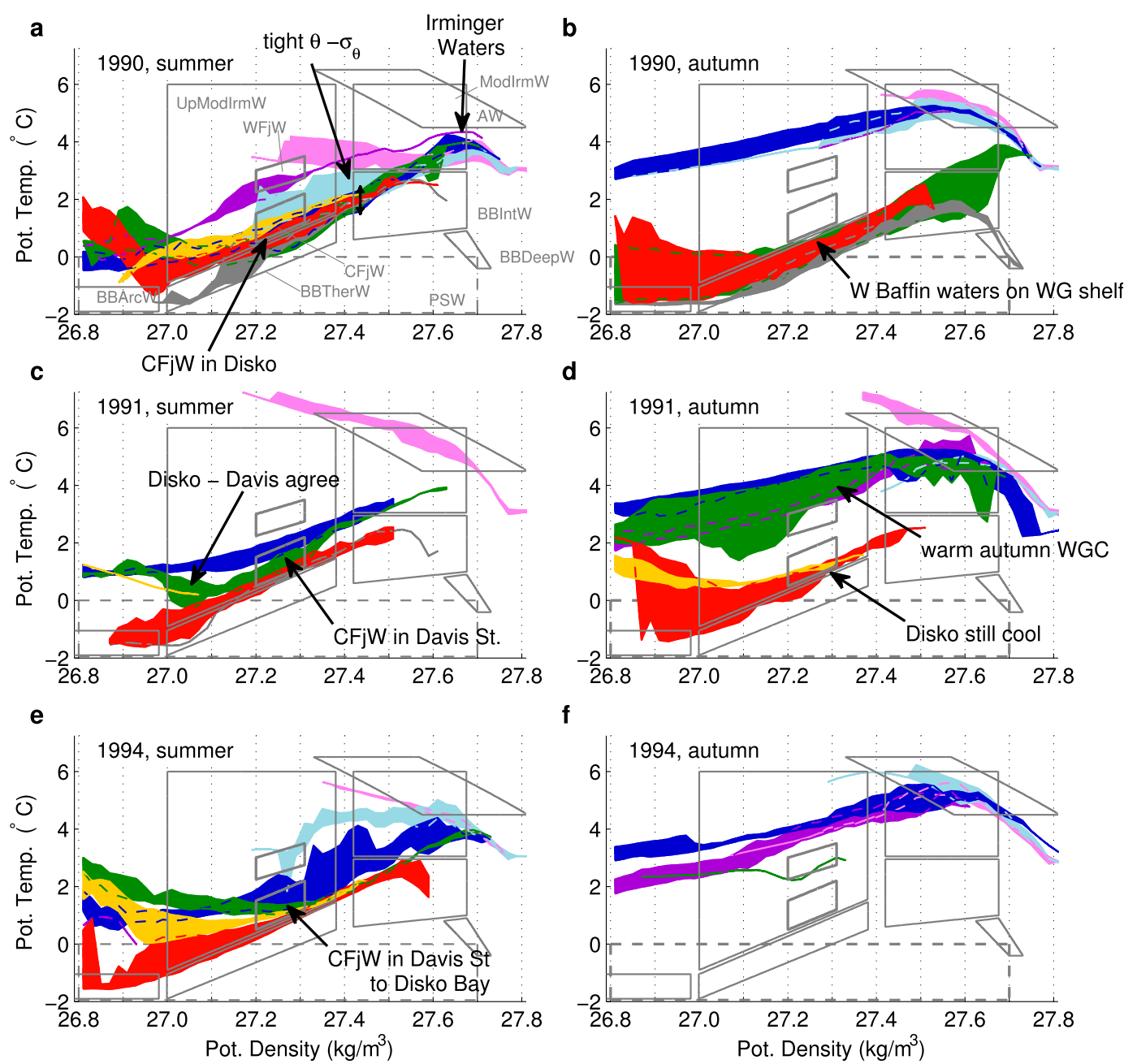

$\mathbf{f}$

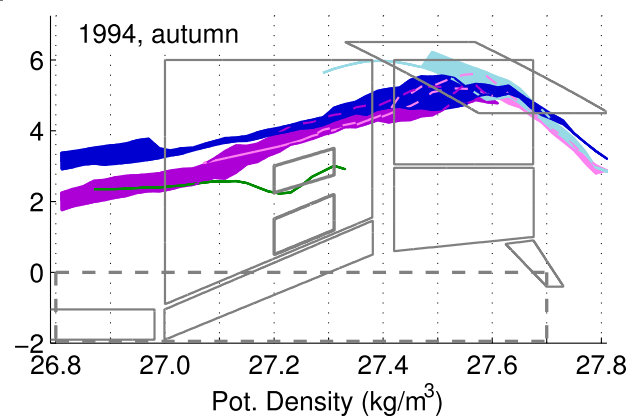

FIG. 6. Potential temperature $\theta$ vs potential density $\sigma_{\theta}$ plots for 1990, 1991, and 1994 CTD profiles falling within regions defined by Fig. 5. Rather than plotting individual CTD profiles, a single color band is plotted for each region. The band is bounded by the $25 \%$ and $75 \%$ percentile potential temperatures $\theta$ (ranging over all profiles in that region). Dashed lines are used to show bands that are otherwise obscured. Water masses defined in Table 2 are shown (light gray lines) for context. Left column is for extended summer months (MJJA) and right column is for autumn (SON).

the south (S) shelf/slope and SW shelf/slope regions together as the West Greenland Current (WGC in figures). We also refer to $S$ deep and $S$ shelf/slope waters in the $\sigma_{\theta}=27.5$ to 27.7 range as Irminger Current waters; these are actually the warmest Irminger Current waters near Cape Farewell (Våge et al. 2011).

In Figs. 6 to 10, we present these data in $\theta-\sigma_{\theta}$ space (rather than $\theta-S_{\mathrm{A}}$ space) since Ilulissat Icefjord basin waters occupy a known, narrow range of potential densities. Straight lines in $\theta-S_{\mathrm{A}}$ space become slightly curved upward in $\theta-\sigma_{\theta}$ space, so mixing lines are distorted, particularly for $\theta>2^{\circ} \mathrm{C}$.

\section{(i) 1990-94}

In summer 1990 (Fig. 6a), the temperature maximum of Irminger Current waters over the southern regions was $4^{\circ} \mathrm{C}$, slightly cooler than $\mathrm{AW}$. For waters denser than $\sigma_{\theta}=27.4$, a relatively tight $\theta-\sigma_{\theta}$ relationship $\left(\sim 1^{\circ} \mathrm{C}\right.$ spread at each $\sigma_{\theta}$ ) held for the SW shelf/slope, Davis Strait, west Greenland outer shelf/slope, and Disko Bay, suggesting that over the time scale of extended summer there was a continuous advective pathway all along the coast at these densities. For $\sigma_{\theta}<27.4$, there was a greater spread of temperatures $\left(>2^{\circ} \mathrm{C}\right)$ in these regions associated with the east-west gradient across Davis Strait and over the west Greenland outer shelf/slope, but Disko Bay waters agreed well with SW Greenland shelf/ slope waters at all densities.

Most importantly, Disko Bay was filled with CFjW in the $27.20 \leq \sigma_{\theta} \leq 27.31$ range. These waters were approximately midway along a mixing line between the almost $4^{\circ} \mathrm{C}$ Irminger Current waters at Cape Farewell 

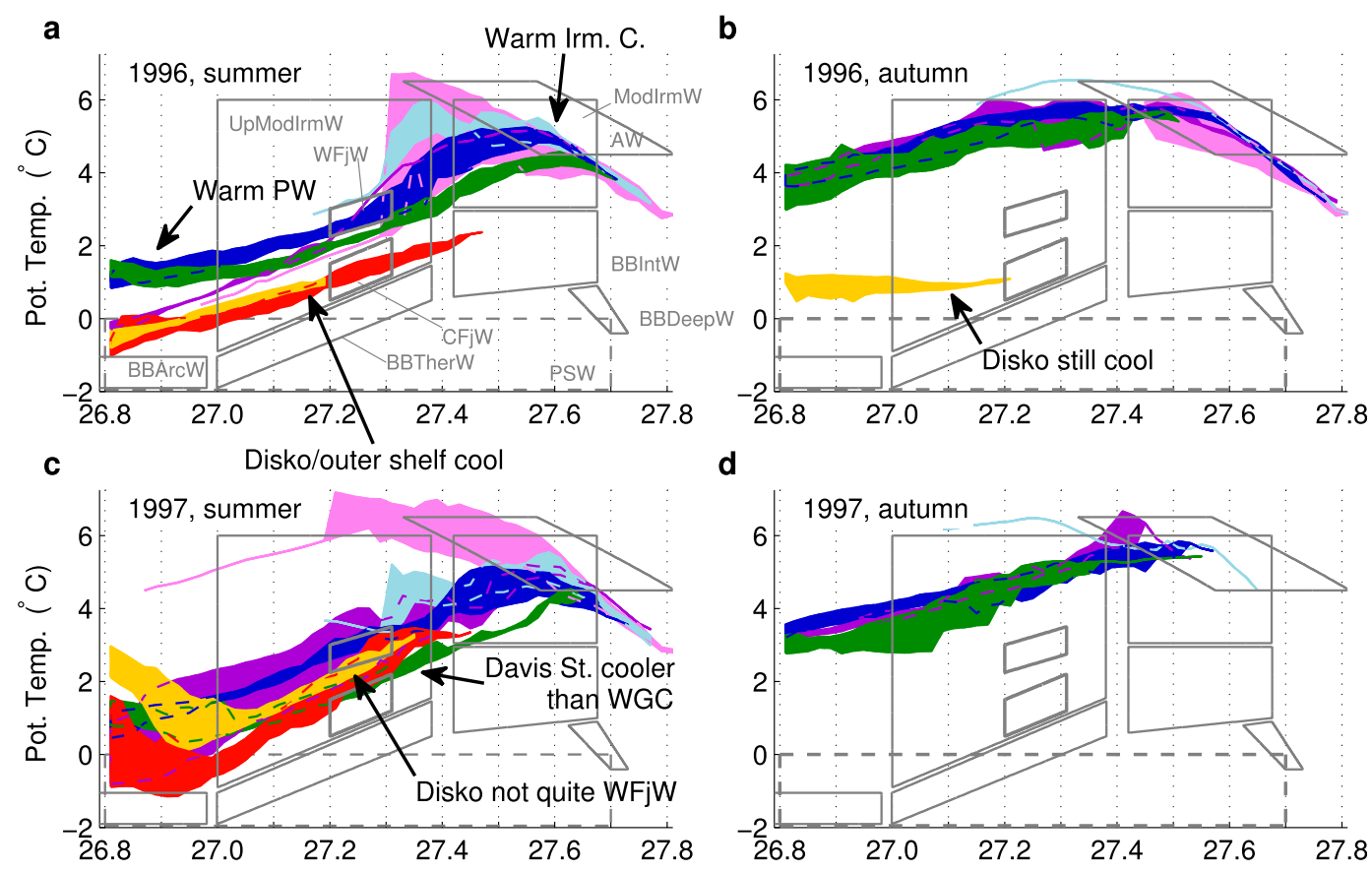

d
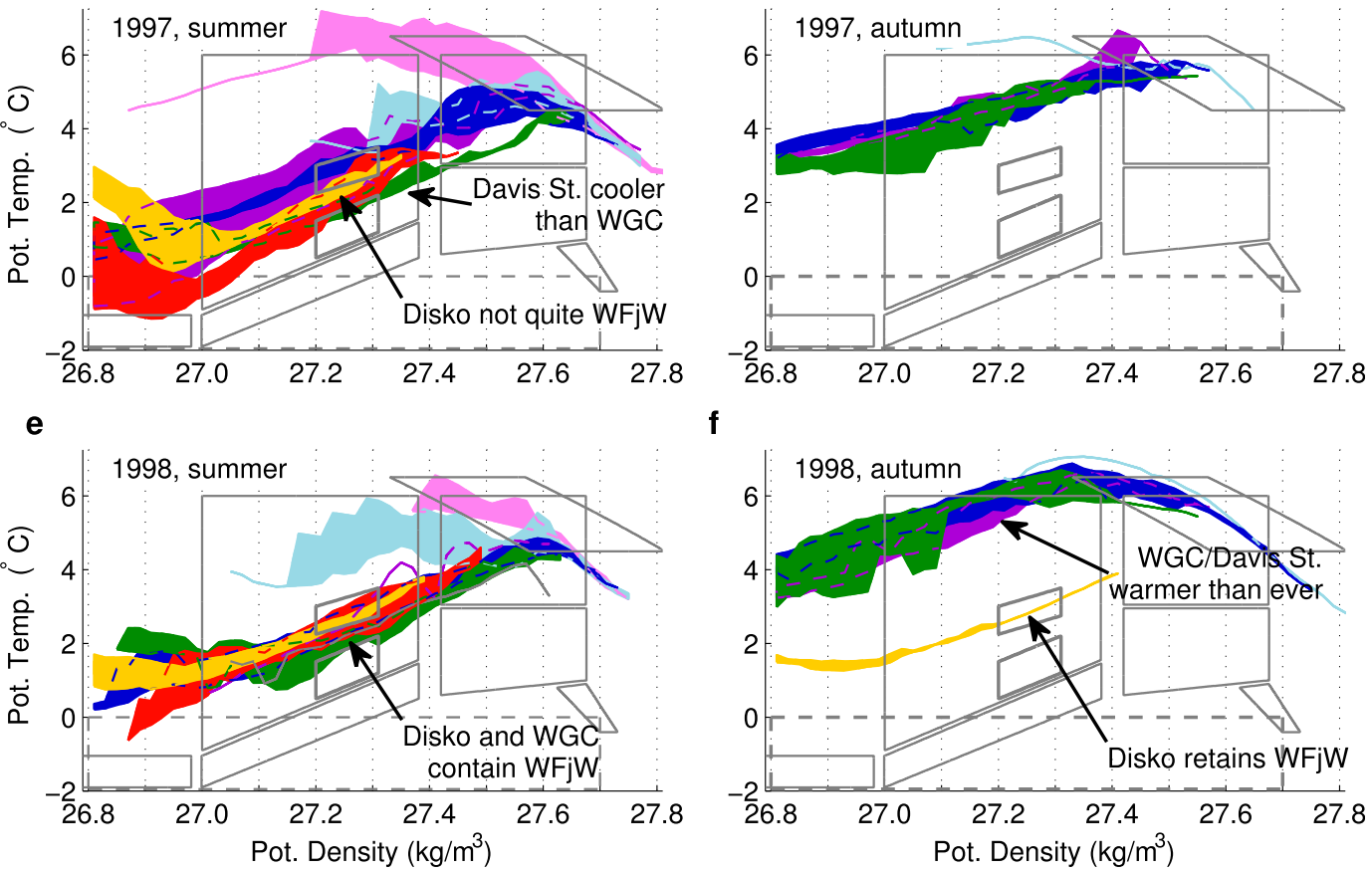

f

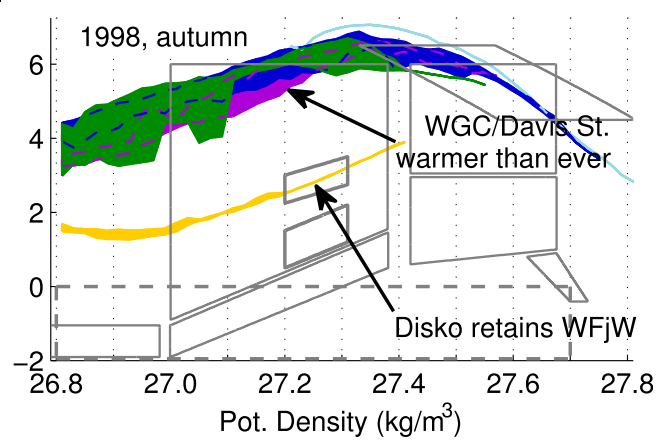

FIG. 7. As in Fig. 6, but for 1996, 1997, and 1998.

and $0^{\circ} \mathrm{C}$ waters at the temperature minimum near $100-\mathrm{m}$ depth throughout the SW shelf/slope. The $0^{\circ} \mathrm{C}$ waters were a remnant of the PSW found down to the $\sigma_{\theta}=$ 27.7 isopycnal in the East Greenland Current north of Denmark Strait (Rudels et al. 2002).

In autumn of 1990 (Fig. 6b), waters on the SW shelf/ slope became $\sim 1^{\circ} \mathrm{C}$ warmer at $\sigma_{\theta}=27.6$ and $\sim 3^{\circ} \mathrm{C}$ warmer for $\sigma_{\theta} \leq 27.4$. Most Davis Strait and west Greenland outer shelf/slope profiles remained at or below their summer 1990 temperatures and overlapped with BBTherW and BBIntW, suggesting that waters originating in western Baffin Bay filled the full width of Baffin Bay north of Davis Strait. No Disko Bay profiles were retrieved in autumn of 1990.

In summer 1991 (Fig. 6c) SW shelf/slope waters were slightly warmer than in 1990 , occupying a $\theta-\sigma_{\theta}$ space between $\mathrm{CFjW}$ and WFjW. DS waters, however, passed through $\mathrm{CFjW}$ as in 1990 and the single DB profile, though shallow, appears to agree with Davis Strait properties better than SW shelf/slope water properties. In autumn of 1991 (Fig. 6d), West Greenland Current and Davis Strait UpModIrmW was again greatly warmed, relative to the preceding summer, for $\sigma_{\theta} \leq 27.5$. Profiles in Disko Bay and on the west Greenland outer shelf/slope, however, still contained CFjW.

In summer 1994 (Fig. 6e), Disko Bay UpModIrmW contained CFjW, in agreement with Davis Strait but on the cool margin of West Greenland Current waters south of the strait. The usual autumn warming occurred along the S and SW shelf/slope, but Davis Strait and Disko Bay were undersampled (Fig. 6f).

\section{(ii) $1996-98$}

In summer 1996 (Fig. 7a), Irminger Current waters near the shelf break off Cape Farewell were distinctly warmer than in 1990 and 1994. Along the SW 

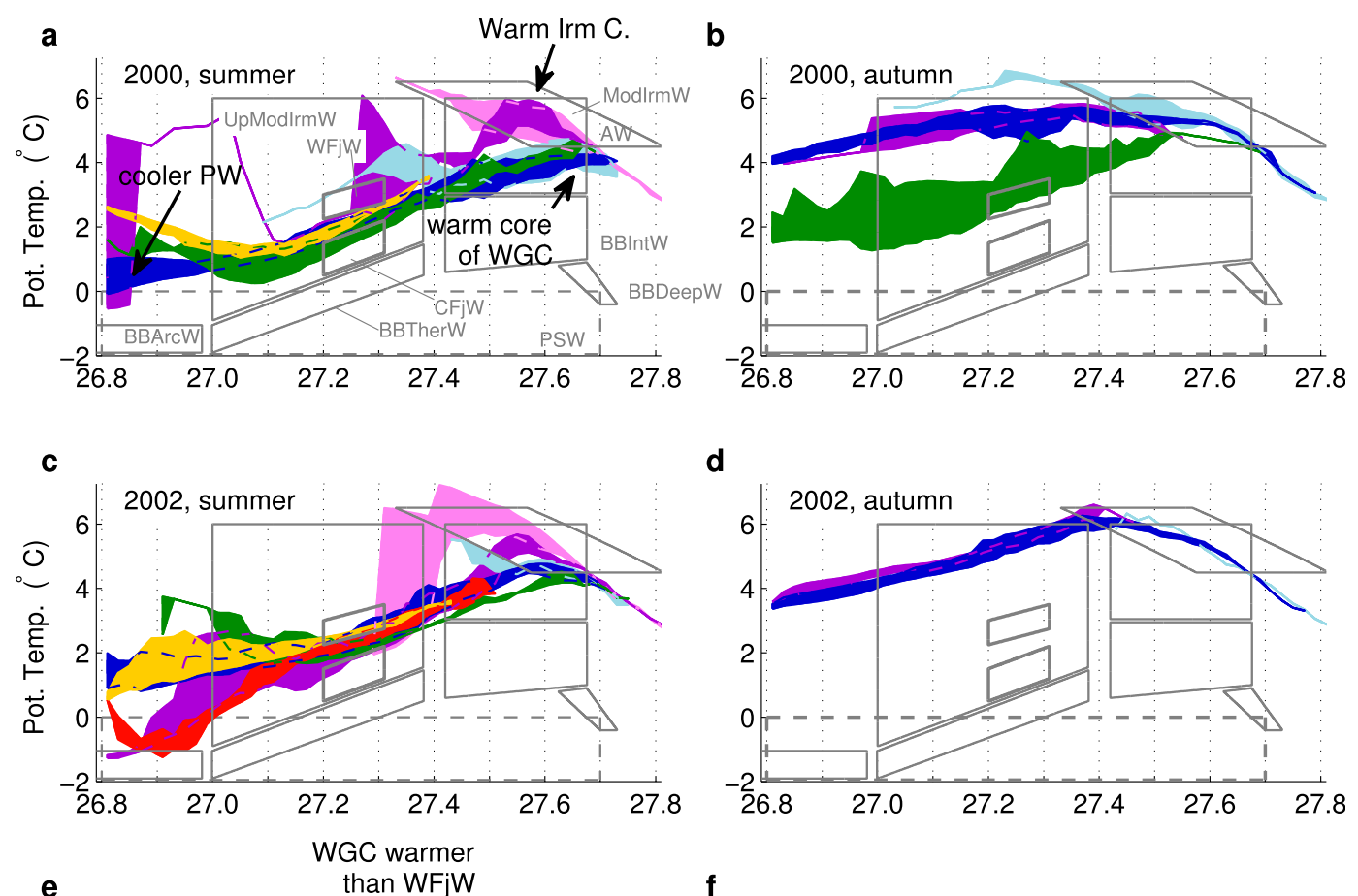

d
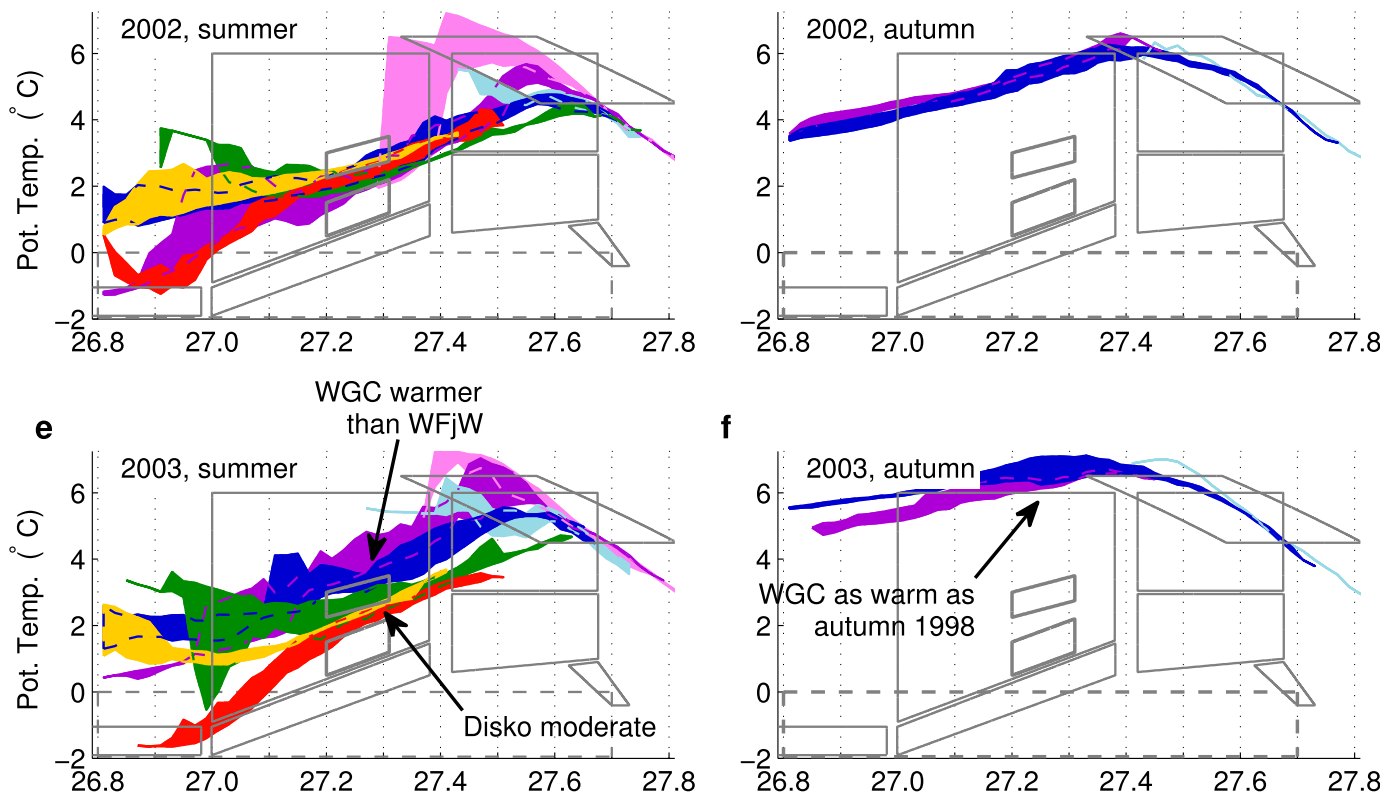

f
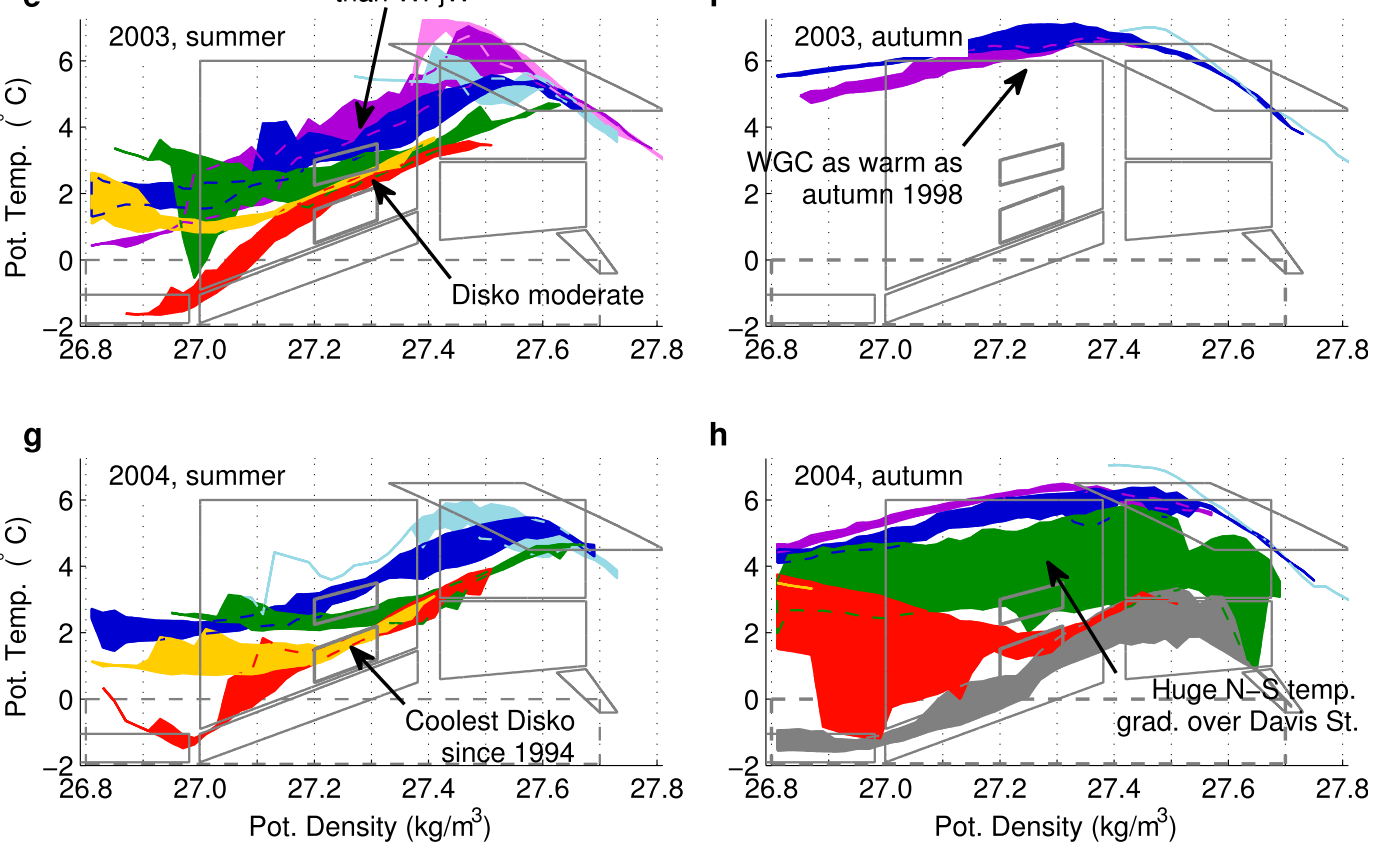

h

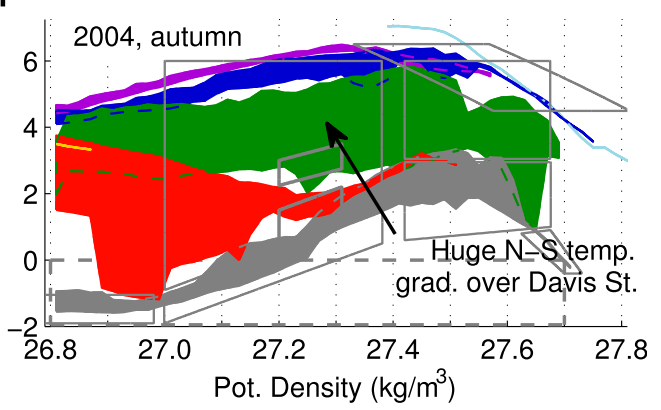

FIG. 8. As in Fig. 6, but for 2000, 2002, 2003, and 2004.

shelf/slope, these $5^{\circ} \mathrm{C}$ waters connected along a mixing line with $1^{\circ}-2^{\circ} \mathrm{C}$ polar waters, with the mixing line passing though WFjW. However, Disko Bay and the west Greenland outer shelf/slope were still filled with $\mathrm{CFjW}$ in this density range and in general fell along a colder mixing line. West Greenland Current temperatures in autumn of 1996 (Fig. 7b) were greater than in 1990-94, as well, although Disko Bay waters with $\sigma_{\theta} \geq 27.1$ did not vary in temperature from summer to autumn, remaining near $\mathrm{CFjW}$.

In summers of 1997 and 1998, warmer temperatures (compared to 1990) at each end again caused the S and SW shelf/slope mixing line to rise, so that UpModIrmW there passed through WFjW rather than $\mathrm{CFjW}$ (Figs. 7c,e). Disko Bay temperatures in summer 1997, however, rose only partway to $\mathrm{WFjW}$ levels, remaining between $\mathrm{CFjW}$ 

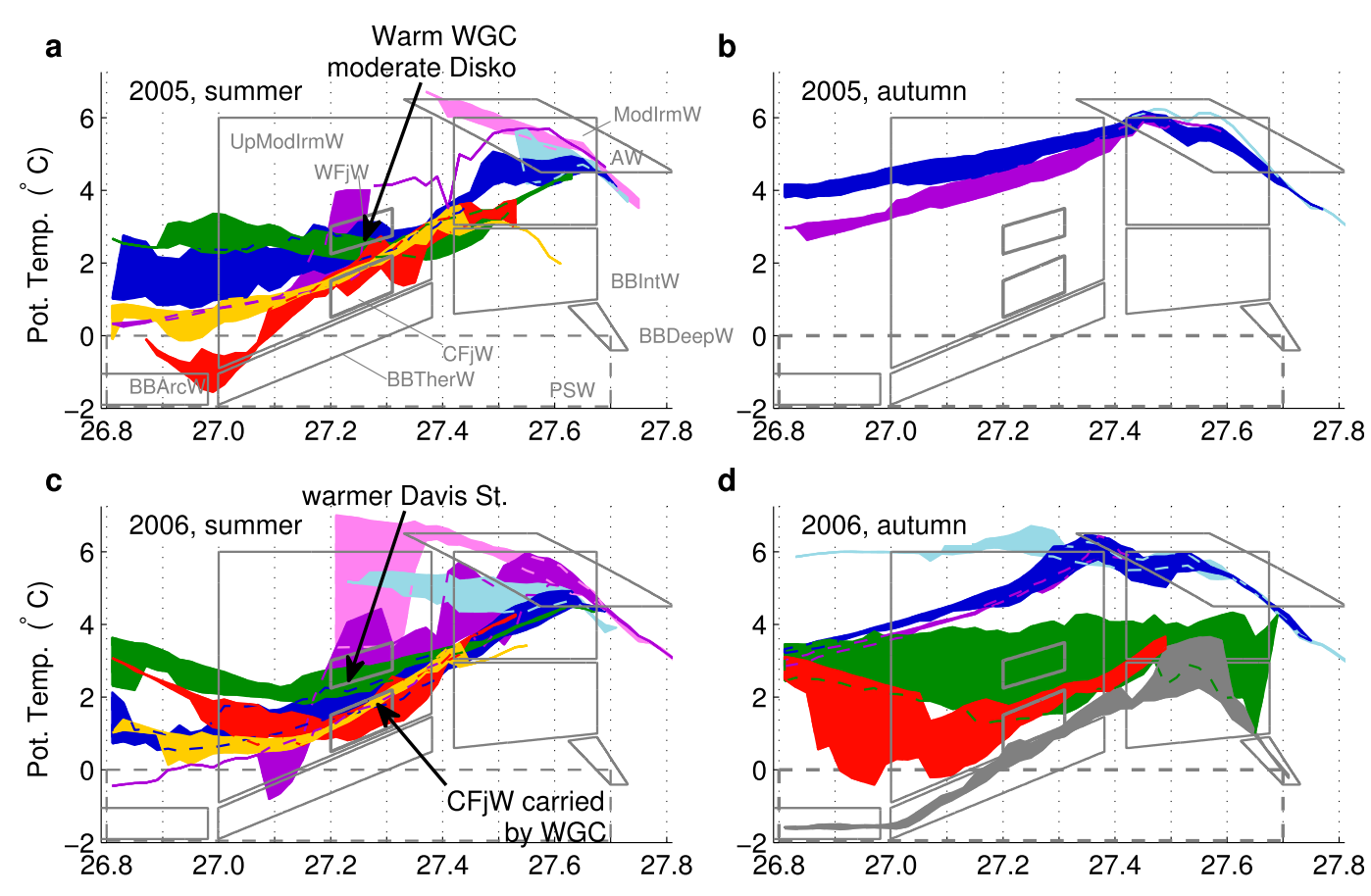

d
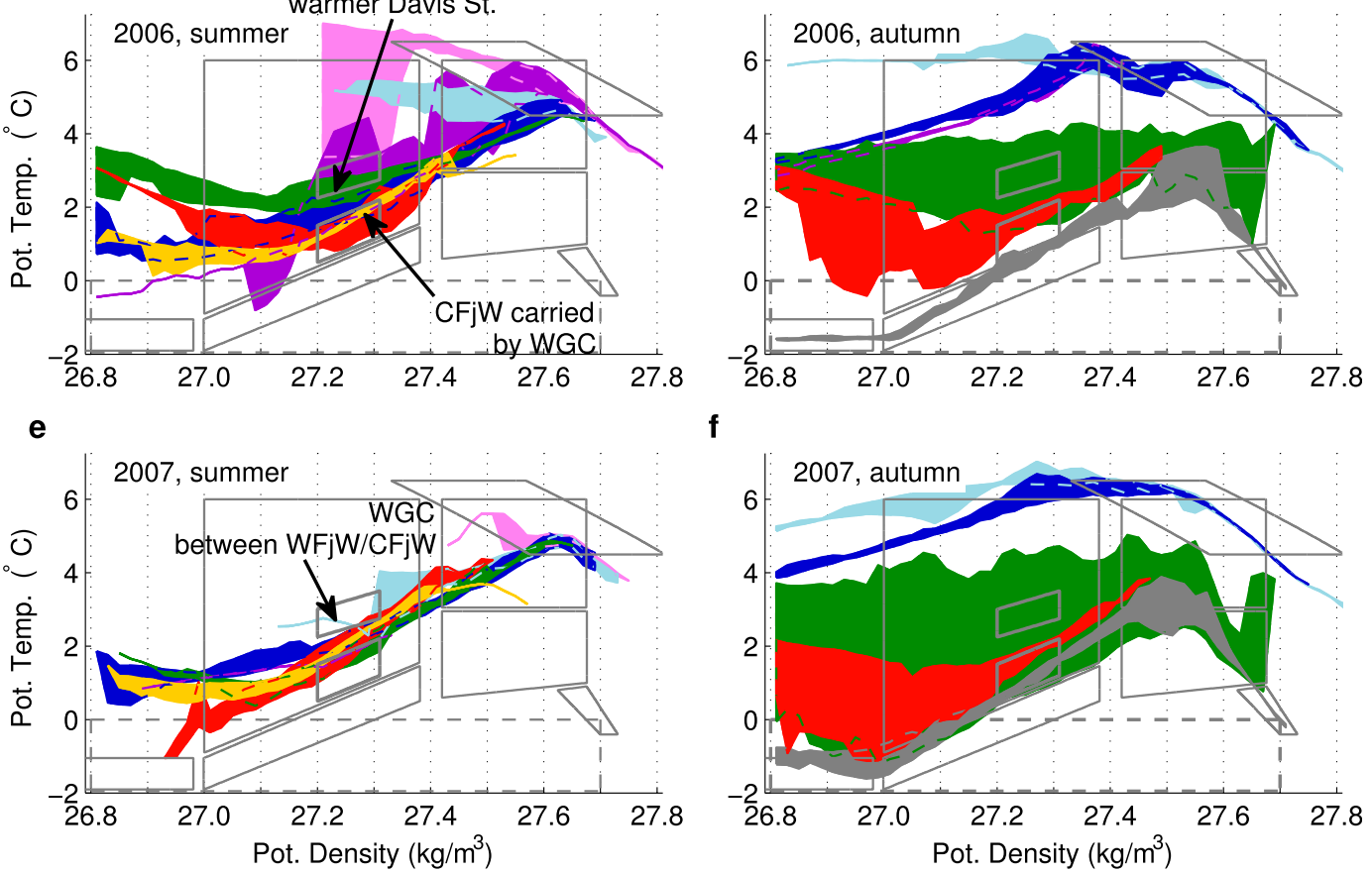

FIG. 9. As in Fig. 6, but for 2005, 2006, and 2007.

and WFjW for most profiles. In summer 1998, the west Greenland outer shelf/slope and Disko Bay were fully consistent with warm West Greenland Current waters to the south. Davis Strait was cooler than the west Greenland outer shelf/slope and Disko Bay waters in summers of 1997 and 1998 in part, possibly, because stations in Davis Strait were occupied in June and early July while most stations in Disko Bay and the west Greenland outer shelf/slope were occupied in mid- to late-August. In autumn 1998, Disko Bay retained WFjW, while the West Greenland Current and Davis Strait waters to the south warmed more than ever (Fig. 7f).

\section{(iii) 2000-04}

Irminger Current waters off Cape Farewell in 2000 were as warm as in 1997/98 (an objective comparison is impossible due to variations in sampling locations and dates), but the warm core of the West Greenland Current along the SW shelf/slope was cooler. Also, the low-salinity shelf water in SW Greenland was on the margin of PSW, as in 1990 (Fig. 8a). The UpModIrmW mixing line therefore passed between $\mathrm{WFjW}$ and $\mathrm{CFjW}$ that summer in the West Greenland Current and Disko Bay.

Data coverage was poor in 2001 (not shown), but Disko Bay waters were again intermediate between WFjW and CFjW and in good agreement with available West Greenland Current profiles.

Summer of 2002 (Fig. 8c) was very similar to summer of 1998, with WFjW detected at the fjord mouth and $2.39^{\circ} \mathrm{C}$ (in situ) waters inside the fjord basin later that winter (Gladish et al. 2015).

Summer of 2003 (Fig. 8e) provided an important contrast to summer of 2002. In both summer and autumn, Irminger Current waters on the $\mathrm{S}$ shelf/slope were warmer than ever and the West Greenland Current in 

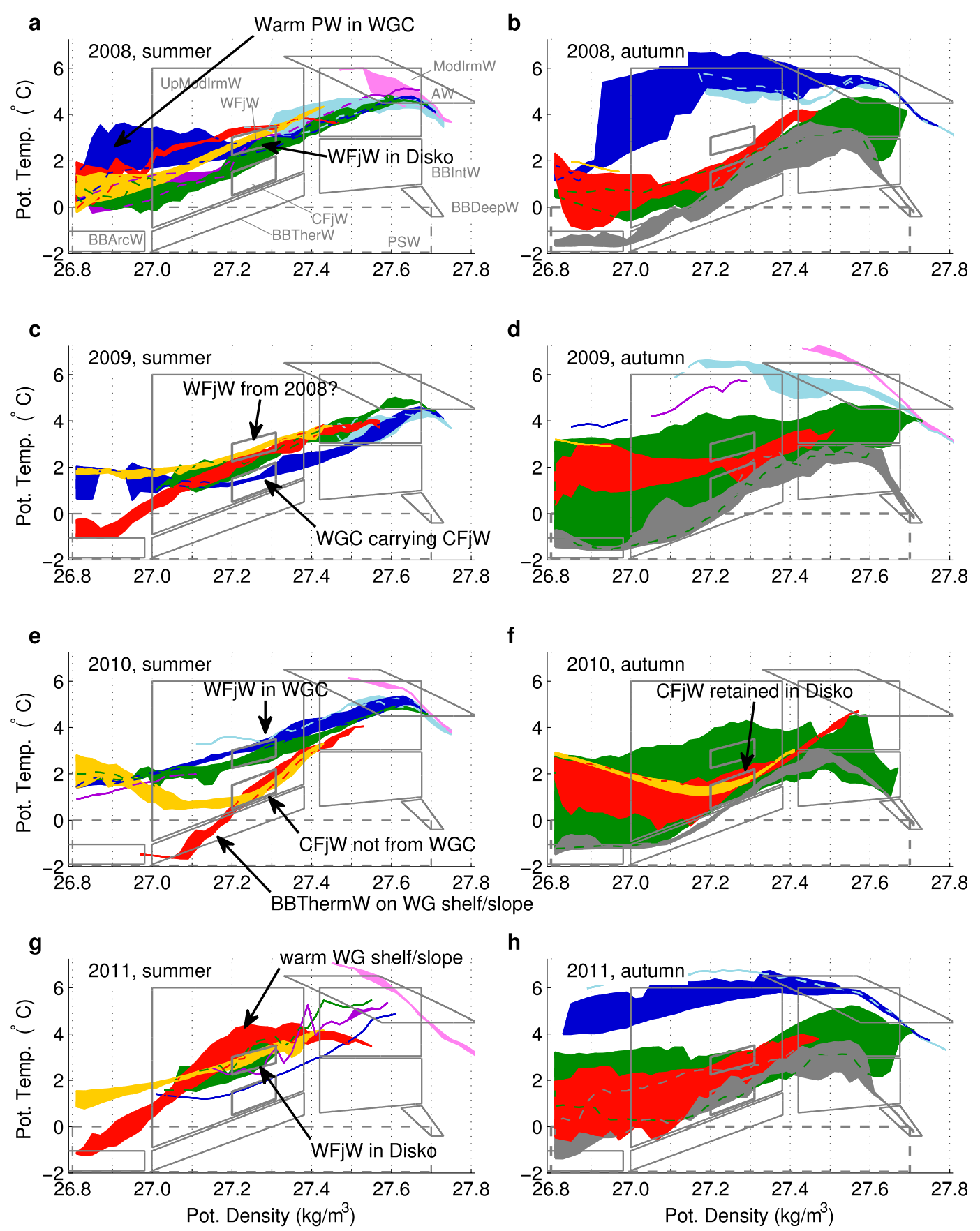

FIG. 10. As in Fig. 6, but for 2008 to 2011.

the $27.20 \leq \sigma_{\theta} \leq 27.31$ range was at least as warm as WFjW, yet Disko Bay waters were cooler than in summer of 2002. The lack of WFjW in Ilulissat Icefjord later that winter (Gladish et al. 2015) shows that undiluted West Greenland Current waters did not flush Disko Bay/Ilulissat Icefjord in the second half of 2003.

Summer of 2004 (Fig. 8g) was substantially similar to summer of 2003, with warm West Greenland Current waters south of Davis Strait but with Disko Bay waters the coolest since 1994 (Table 1). West Greenland Current waters underwent the usual autumn warming in 2004 (above $4^{\circ} \mathrm{C}$ for all $\sigma_{\theta} \geq 26.8$; Fig. 8h). Better sampling across Davis Strait that season showed there was a large thermal gradient on isopycnals from south to north, with waters in the south similar to West Greenland Current waters and those to the north remaining 
close to the cool conditions seen earlier in the summer north of Davis Strait.

\section{(iv) 2005-07}

In summer 2005 (Fig. 9a), West Greenland Current data were sparse, but the overall pattern appears substantially similar to 1997 and 2003 with a warm West Greenland Current and intermediate Disko Bay temperatures.

In 2006, SW shelf/slope waters from mid-May just grazed $\mathrm{CFjW}$ in $\theta-\sigma_{\theta}$ space, while Disko Bay waters from mid-July passed entirely through the CFjW definition (Fig. 9c). It appears that the cool waters of Disko Bay and Ilulissat Icefjord that year may have been carried there by a cool West Greenland Current, as in 1990 and 1994. It also suggests the possibility, however, that the cooler Disko Bay waters in 2003 and 2004 were actually carried there by a seasonally varying West Greenland Current that was warmer in late June when it was sampled than in the spring when it carried waters that would arrive in Disko Bay later in the summer. Assuming a speed of $0.35 \mathrm{~m} \mathrm{~s}^{-1}$ south of Davis Strait (Cuny et al. 2002) and $0.15 \mathrm{~m} \mathrm{~s}^{-1}$ from the strait into Disko Bay, the travel time for West Greenland Current waters from Cape Farewell to Ilulissat Icefjord is about 90 days.

In summer of 2007 (Fig. 9e), profiles from SW shelf/ slope to Disko Bay essentially overlapped in $\theta-\sigma_{\theta}$ space, and the intermediate temperatures in Disko Bay can be attributed to waters of intermediate temperature in the West Greenland Current.

\section{(v) 2008-11}

In summer of 2008 (Fig. 10a), Disko Bay had a layer of WFjW across it, consistent with a warm West Greenland Current. While the AW end member of the SW shelf/ slope mixing line was slightly cooler than in 2007, the low-salinity polar water end member was unusually warm, tilting the mixing line upward. In this instance, the warmth of Disko Bay seems related to anomalous heating of the West Greenland Current polar waters. In autumn, low-salinity West Greenland Current waters at $\sigma_{\theta}=27.0$ reached almost $6^{\circ} \mathrm{C}$, which occurred in only two other years (2003 and 2011). Davis Strait waters were unusually cool in autumn of 2008 (Fig. 10b) compared to previous years (but this could be a sampling bias).

In June 2009 (Fig. 10c), the West Greenland Current was carrying CFjW northward while Disko Bay was in a warm state, possibly retained from the previous year.

The West Greenland Current up to Davis Strait was distinctly warm in summer 2010 (Fig. 10e), yet Disko Bay and the west Greenland outer shelf/slope were even colder than in 2004. Either the West Greenland Current was anomalously cool in early 2010 or else Disko Bay waters contained a larger than usual fraction of
BBTherW. We favor the second explanation for multiple reasons (discussed further below), including the fact that BBTherW was actually present at $\sigma_{\theta}=27.2 \mathrm{~kg} \mathrm{~m}^{-3}$ near the Egedesminde Dyb trough (red band, Fig. 10e). In autumn of 2010 (Fig. 10f), Disko Bay retained CFjW, implying that the warm West Greenland Current waters of the summer had not entered Disko Bay.

In summer of 2011 (Fig. 10g), warmer than ever waters filled Disko Bay and the west Greenland outer shelf/ slope. The West Greenland Current was not sampled enough to relate it to these particularly warm waters.

\section{2) SUMMARY OF WEST GREENLAND VARIABILITY,} 1990-2011

UpModIrmW properties in Disko Bay in the summers of 1990, 1998, 2000, 2002, and 2006-08 agreed with waters along the SW shelf/slope, and therefore interannual variations in those years were likely carried to Disko Bay in the West Greenland Current. Temperature variations in both the Irminger-derived temperature maximum and the East Greenland Current-derived temperature minimum were jointly responsible for the $\sim 1{ }^{\circ} \mathrm{C}$ interannual variations carried into Disko Bay and Ilulissat Icefjord. In 1991, 1994, 1997, and 2005, the continuity of water properties was ambiguous; we make no further comments about these years. Summers when there was a clear disagreement between Disko Bay UpModIrmW and waters over the SW shelf/slope were 1996, 2003, 2004, 2009, and 2010.

In the summers with clear disagreement, UpModIrmW in the West Greenland Current was cooler than in Disko Bay only in 2009. Otherwise UpModIrmW in Disko Bay was cooler. In 1996 and 2010, autumn waters in Disko Bay were still cool, implying that the warm West Greenland Current waters never reached Disko Bay (no autumn observations in 2003 and 2004). However, in 1996, 2003, 2004, and 2010, cool UpModIrmW in Disko Bay was in agreement with UpModIrmW water on the west Greenland outer shelf/slope, suggesting that exchange had occurred across the shelf. Greenland shelf waters north of Davis Strait were cool those years because either 1) the West Greenland Current had delivered cool waters earlier in the spring across Davis Strait or 2) BBTherW waters normally confined to the west and central part of Baffin Bay had mixed (along isopycnals) with UpModIrmW from the West Greenland Current, creating a cool product that spread over the west Greenland shelf and into Disko Bay. The available evidence is insufficient to decide in general in favor of hypothesis 1 or 2 . The fact that there was a large annual cycle in UpModIrmW temperatures in Davis Strait over the west Greenland slope (Fig. 4a), which reached its minimum typically before midsummer CTD 
profiles were collected, supports hypothesis 1 (possibly explaining the cool 2006, for instance). The presence of BBTherW at mooring WG1-151 in early 2010 and the exceptionally warm West Greenland Current in summer of 2010 favors hypothesis 2 in that case.

\section{3) SMALL INTERANNUAL CHANGES, LARGE SEASONAL CYCLE}

Relative to the large seasonal cycle in UpModIrmW temperatures in the West Greenland Current, the interannual temperature changes we observed in Ilulissat Icefjord were quite small, which makes explaining those temperature changes inherently delicate. Every autumn UpModIrmW appeared in Davis Strait that, if it had entered Disko Bay, would have been much warmer than any UpModIrmW observed in the bay since 1980 (Gladish et al. 2015) and probably in at least the past $100 \mathrm{yr}$ (Lloyd et al. 2011). It is known that the West Greenland Current, which travels about $0.35 \mathrm{~m} \mathrm{~s}^{-1}$ above the SW shelf/slope, splits at Davis Strait with a large majority of its waters turning to the west to eventually join the Labrador Current (Cuny et al. 2002). However, it is not true that the autumn warm signal failed to cross Davis Strait simply because the already weak northward flow ceased in autumn. Mean northward currents of $0.1-0.2 \mathrm{~m} \mathrm{~s}^{-1}$ over the west Greenland shelf/slope at Davis Strait in autumn are normal (Tang et al. 2004; Cuny et al. 2005; Curry and Lee 2011; Curry et al. 2014).

Stations on the west Greenland outer shelf/slope were never occupied late enough in the year, however, to determine whether the late-autumn warm signal in Davis Strait really propagated into outer Egedesminde Dyb. The closest we come to being able to test this is from October profiles in 2006, 2007, and 2009 on the west Greenland outer shelf. UpModIrmW in these profiles was at least $1^{\circ} \mathrm{C}$ cooler than in Davis Strait. However, besides being possibly too early in the autumn to see the autumn/winter warm pulse, these profiles were all from a section north of the entrance to Egedesminde Dyb and could have missed a warm inflow banked against the southern wall of the trough. Supposing that some of the $5^{\circ}-6^{\circ} \mathrm{C}$ UpModIrmW does cross Davis Strait in autumn/winter, why does it not enter Disko Bay/Ilulissat Icefjord? We address this question using the Davis Strait mooring data below.

\section{c. Seasonal cycle from moorings}

\section{1) Geostrophic Velocities THROUGH DAVIS STRAIT}

Figure 11 shows seasonally averaged geostrophic velocities across Davis Strait, derived using the thermal wind relation with densities interpolated across the temperature-salinity ( $\mathrm{T}-\mathrm{S}$ ) moorings and referenced to acoustic Doppler current profiler (ADCP) velocities averaged over the upper $100 \mathrm{~m}$. The largely barotropic West Greenland Current was generally strongest in autumn, which is consistent with Tang et al. (2004) and Cuny et al. (2005). The southward Baffin Current was usually surface intensified and usually covered most of Davis Strait, leading to high horizontal shear just west of the Greenland slope.

Northward transports over the Greenland slope and shelf (where data are available) appeared typical in the first half of 2006, the first year with abundant CFjW covered by this dataset. This supports the hypothesis that cool Ilulissat Icefjord waters originated in the West Greenland Current that summer.

The weak West Greenland Current transport above $\sigma_{\theta}=27.3$ in the first half of 2007 possibly explains the sigmoidal shape of Disko Bay profiles in 2007 (Fig. 9e), with waters above the $\sigma_{\theta}=27.2$ isopycnal appearing to lie along a cooler mixing line than waters below the $\sigma_{\theta}=$ 27.3 isopycnal.

The West Greenland Current was particularly weak during summer of 2010, with mean velocities being southward across Davis Strait from Baffin Island to the west Greenland shelf in July. The fact that UpModIrmW was not flowing toward the shelf west of Disko Bay in July 2010 is consistent with the hypothesis that Ilulissat Icefjord contained an unusually large fraction of cold BBThermW then. However, Disko Bay already contained CFjW in May and June of 2010 before the West Greenland Current stagnated.

Figure 11 also shows that the crucial $\sigma_{\theta}=27.3$ contour was typically at or slightly above the depth of the Egedesminde Dyb Sill in autumn. We hypothesize that the inflow of waters in the $\sigma_{\theta}=27.2$ to 27.3 range was therefore topographically controlled by the Egedesminde Dyb Sill and consequently impeded such that relatively little warm autumn water entered Disko Bay [as in schematic Fig. 6 of Whitehead (1998)]. This isopycnal gate was most open in winter and spring of each year, but with an illuminating exception. In 2009, there was no data from slope mooring C5-500 until the autumn redeployment, but the easternmost deep mooring C4500 was anomalously low-density in winter (2008/09), showing that the isopycnal gate was closed (or less open than usual) that winter. In spring of 2009, the flow of the West Greenland Current was weak, and the isopycnal gate appears to have remained less open than usual (compared to spring of 2005-07 or 2010/11), although the missing data from C5-500 makes this uncertain. The weak current and apparent blockage of these crucial isopycnals in early 2009 could explain the failure of cool 

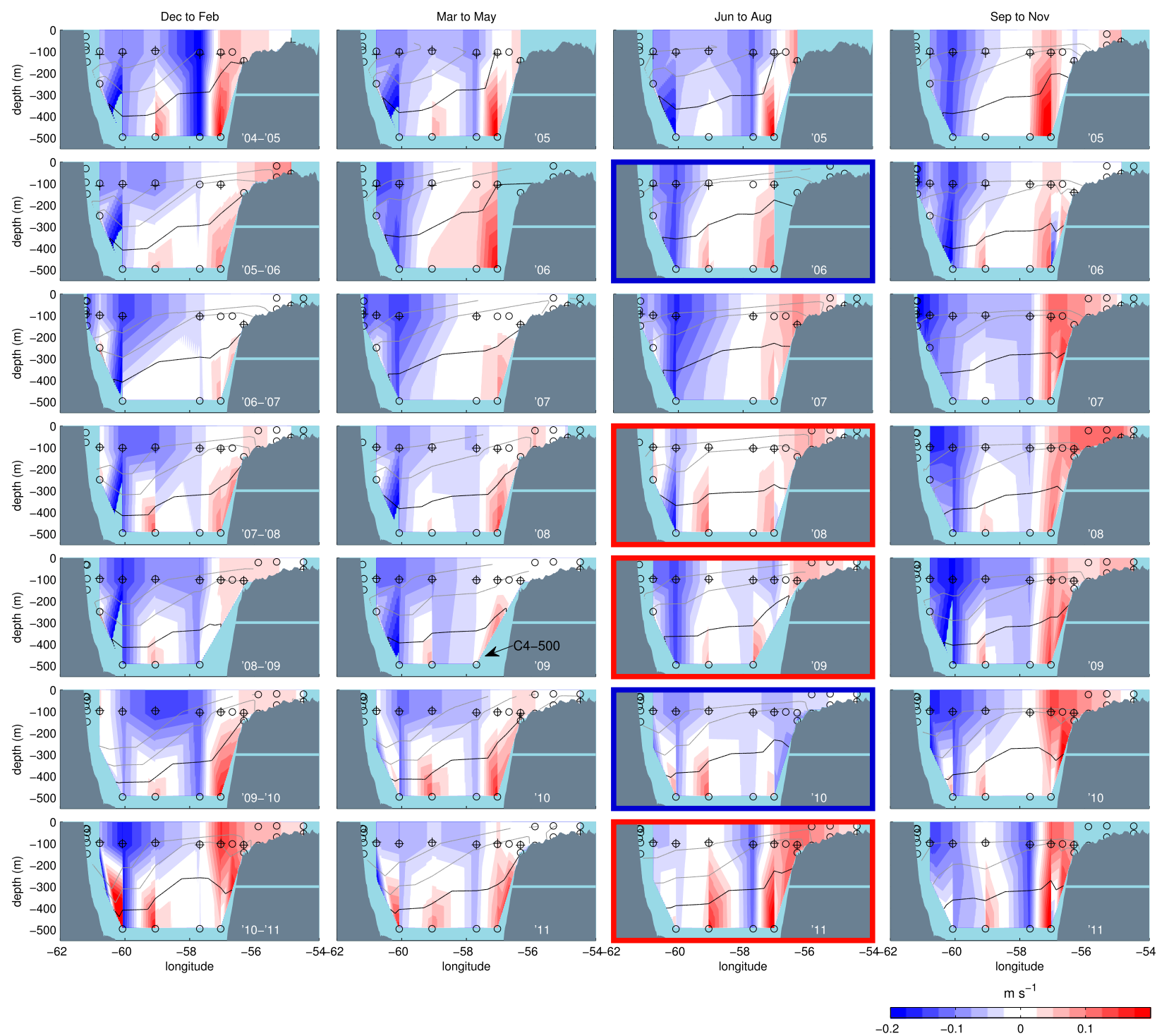

FIG. 11. Geostrophic velocities transverse to the Davis Strait mooring line, using potential densities interpolated between $T-S$ moorings (black circles) and referenced to ADCP mooring (black crosses) velocities in the upper $100 \mathrm{~m}$. Pale blue areas are outside of the interpolation area of the moorings while dark gray areas are seabed (IBCAO V3). The pale blue line through the Greenland shelf is at $300 \mathrm{~m}$, the depth of the Egedesminde Dyb Sill. Gray lines are the 26.7 and $27.0 \mathrm{~kg} \mathrm{~m}^{-3}$ isopycnals, and the black line is the $27.3 \mathrm{~kg} \mathrm{~m}{ }^{-3}$ isopycnal. Blue and red boxes distinguish cool and warm summers, as in Table 1.

West Greenland Current waters (Fig. 10c) to enter Disko Bay that year, leaving the warmer 2008 waters in place.

Unusually high densities over the west Greenland slope lifted the $\sigma_{\theta}=27.3$ isopycnal well above the depth of the Egedesminde Dyb Sill from winter 2009/10 to spring 2010, implying that the flow of water over Egedesminde Dyb Sill may have been larger than normal in early 2010.

In winter 2010/11, isopycnals on the shelf were depressed and the isopycnal gate was closed. Spring of 2011 was closer to typical, however, and this was followed by the strongest observed West Greenland
Current of any summer bringing warm water toward the gate. A surge of warm West Greenland Current waters in mid-2011 must be responsible for the record warm waters on the west Greenland outer shelf/slope (Fig. 10g) and in Disko Bay (Table 1) in summer of 2011.

\section{2) SPATIAL PATTERNS OF SEASONAL VARIABILITY}

To better understand the spatial pattern of variability across Davis Strait, we analyzed the covariability of the $\mathrm{T}-\mathrm{S}$ moorings with good temporal coverage. The nine moorings used were W1-150, W2-75, C5-502, C5-105, C4502, C4-105, C2-502, C2-105, and C1-105 (Figs. 1, 2a). 

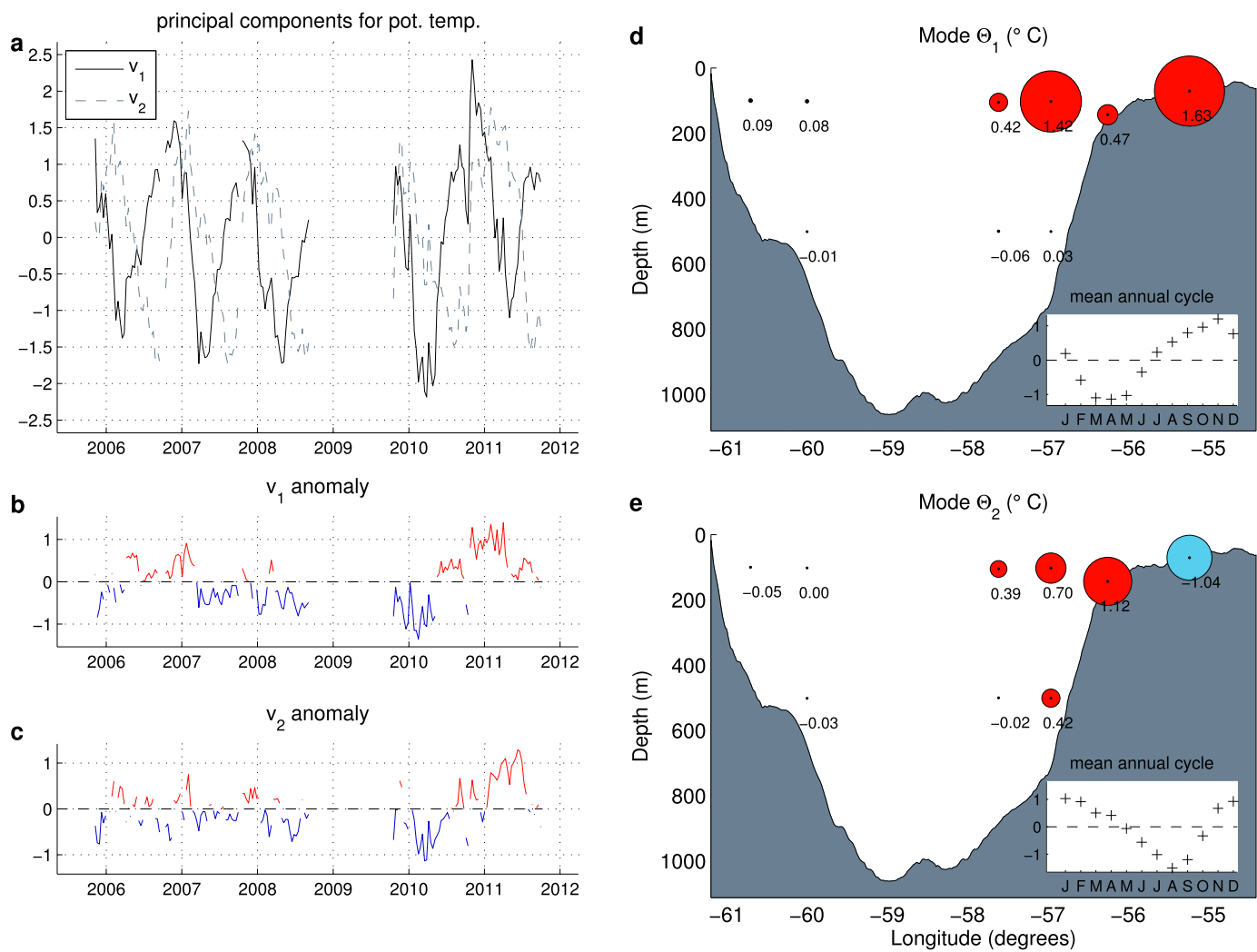

FIG. 12. EOF analysis of potential temperatures from nine Davis Strait moorings. After removing the mean from each mooring time series, the vector time series $\boldsymbol{\theta}(t)$ of all mooring temperatures was decomposed as $\boldsymbol{\theta}(t)=\boldsymbol{\Theta}_{1} v_{1}(t)+\boldsymbol{\Theta}_{2} v_{2}(t)+\cdots$, where the dimensionless coefficient time series $v_{k}(t)$ were mutually orthogonal with unit variance, and the modes (i.e. vectors) $\boldsymbol{\Theta}_{k}$ were mutually orthogonal. Modes $\boldsymbol{\Theta}_{1}$ and $\boldsymbol{\Theta}_{2}$ together account for $76 \%$ percent of the moorings' covariance $\left(\Theta_{1}\right.$ contributes 47\%). (a) Coefficient time series $v_{1}(t)$ and $v_{2}(t)$ are shown. (b), (c) Monthly averaged anomalies of $v_{1}(t)$ and $v_{2}(t)$, relative to the long-term monthly averages. (d) Dots mark the locations of nine moorings used in the EOF analysis, plotted over the bathymetry of Davis Strait. The dot's color and size are proportional to the amplitude from $\boldsymbol{\Theta}_{1}$ for each mooring (also written next to each mooring). The inset time series is the long-term monthly averaged $v_{1}(t)$. (e) As in (d), but for $\boldsymbol{\Theta}_{2}$ and $v_{2}(t)$.

Figure 12 shows the two leading patterns of covariability of potential temperature for these moorings. Mode $\Theta_{1}$ captured much of the annual warming over the Greenland shelf and slope, reaching a maximum in November (Fig. 12d, inset). Mode $\Theta_{2}$ captures the fact that the shallow shelf mooring W2-75 generally reached its maximum temperature in September (not shown), slightly earlier than $\Theta_{1}$, while shelf slope/break moorings generally reached their maximum temperature in December (not shown), slightly later than $\Theta_{1}$. Overall, waters over the west Greenland shelf/slope down to 150-m depth were warmest from September to February, reaching about $1.5^{\circ}-2^{\circ} \mathrm{C}$ above their annual mean, and coolest from March to August, reaching $1.5^{\circ}-2^{\circ} \mathrm{C}$ below their annual mean. Waters at $500 \mathrm{~m}$ on the slope (roughly, the West Greenland Current temperature maximum) projected strongly on the second mode and had about a $0.8^{\circ} \mathrm{C}$ minimum-to-maximum annual variation (the smallness of which is consistent with the tilting rather than lifting of the West Greenland Current mixing line in autumn). On the west side of Baffin Bay, temperature variations were much smaller.

Waters over the Greenland slope and shelf may have been warmest in autumn and winter, but Fig. 13 shows that this is when they were the least dense, as well. Mode $\Sigma_{\theta 1}$ captured the tilting of isopycnals up toward the Greenland shelf in spring (maximum in April; Fig.13d, inset), with the Greenland shelf undergoing densification and the Baffin Current becoming somewhat less dense, and the flatting of isopycnals in autumn (flattest in September). Mode $\Sigma_{\theta 2}$ captured a general densification of both continental shelves peaking in June (Fig. 13e, inset) and reaching a minimum in midwinter. Adding the two modes together (not shown) shows that the waters over the Baffin slope were densest in late summer when they were the most saline and least dense in midwinter when they were the least saline, while waters over the Greenland shelf were densest in spring 

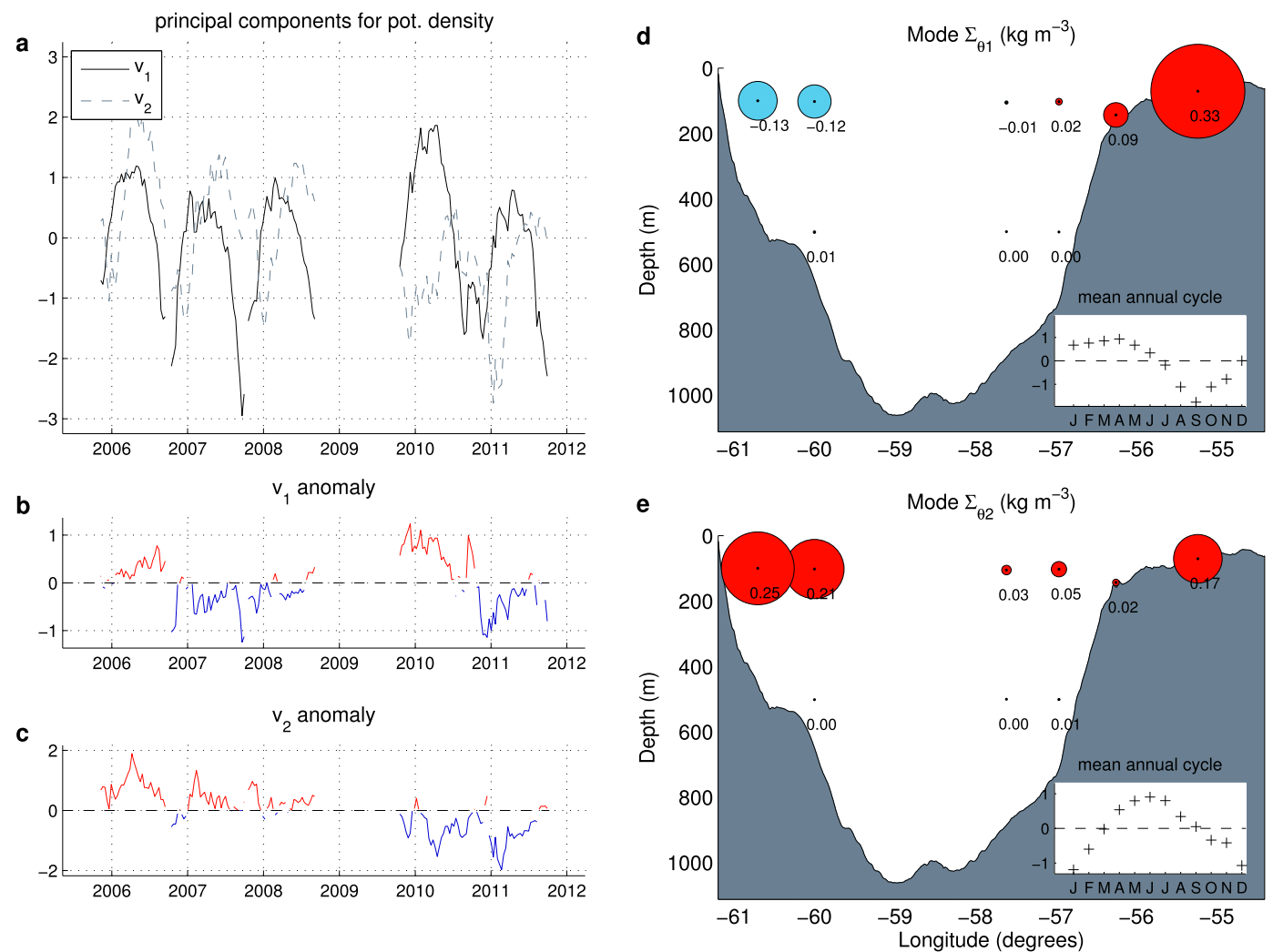

FIG. 13. As in Fig. 12, but for potential density $\sigma_{\theta}$. Modes $\Sigma_{\theta 1}$ and $\Sigma_{\theta 2}$, which contribute about equally, account for $89 \%$ of the moorings' covariance.

when saltiest and least dense in autumn when least saline (salinity modes shown in Fig. 14).

Temperature anomalies were most conspicuous in early 2010 and early 2011. In early 2010 , waters over the Greenland shelf and slope were $0.5^{\circ}$ to $2^{\circ} \mathrm{C}$ cooler than usual, and in early 2011 they were warmer than usual by about the same amount (Figs. 12b,c). These anomalies showed up also in density, with the cool Greenland shelf waters of 2010 being denser and those of 2011 being less dense (Figs. 13b,c).

An important difference between the two cool summers 2006 and 2010 was that Baffin Current waters had a large positive salinity anomaly in 2006 but a large negative anomaly in 2010 (Fig. 14b). Baffin Current densities were consequently higher than usual in 2006 (mode $\Sigma_{\theta 2}$; Fig. 13c) and low in early 2010 (both modes; Figs. 13b,c). Consequently, the isopycnal tilt across Baffin Bay was much greater in early 2010 than in early 2006.

\section{3) WHY DO WARM AUTUMN/WINTER WEST GREENLAND CURRENT WATERS NOT ENTER DISKO BAY?}

From the moorings' seasonal cycles, we infer that during autumn and winter the low-density waters flooding the west Greenland continental shelf push down critical isopycnals, making exchange over the topographic barriers more difficult, precisely when the waters of the outer shelf are warmest. According to CTD profiles near the west Greenland shelf break, the mean vertical density gradient between $100-$ to $300-\mathrm{m}$ depth is typically $2.2 \times 10^{-3} \pm 4 \times 10^{-4} \mathrm{~kg} \mathrm{~m}^{-4}$. The annual oscillation in density at the shelfbreak mooring WG1-151 of about $0.3 \mathrm{~g} \mathrm{~kg}^{-1}$ (Fig. 4) therefore corresponds, under the assumption that the mean background stratification does not change much over the year, to vertical isopycnal displacements of about $\Delta z=$ $\Delta \rho /(\partial \rho / \partial z)=140 \mathrm{~m}$. The $\sigma_{\theta}=27.4$ isopycnal, which grazes the Egedesminde Dyb Sill in June (Fig. 3d), is therefore interrupted by the sill during autumn/winter, and the $\sigma_{\theta}=27.3$ isopycnal, which was at $150-\mathrm{m}$ depth just west of the sill in June 2007, would be at about the sill depth in autumn/winter.

The isopycnals on the west Greenland shelf in Davis Strait rose to their maximum height in spring each year (Fig. 13d), and therefore it is in the spring when inflow into Disko Bay was likely the greatest. If true, waters that fill Disko Bay and Ilulissat Icefjord below sill depths in spring are potentially locked-in until the following 

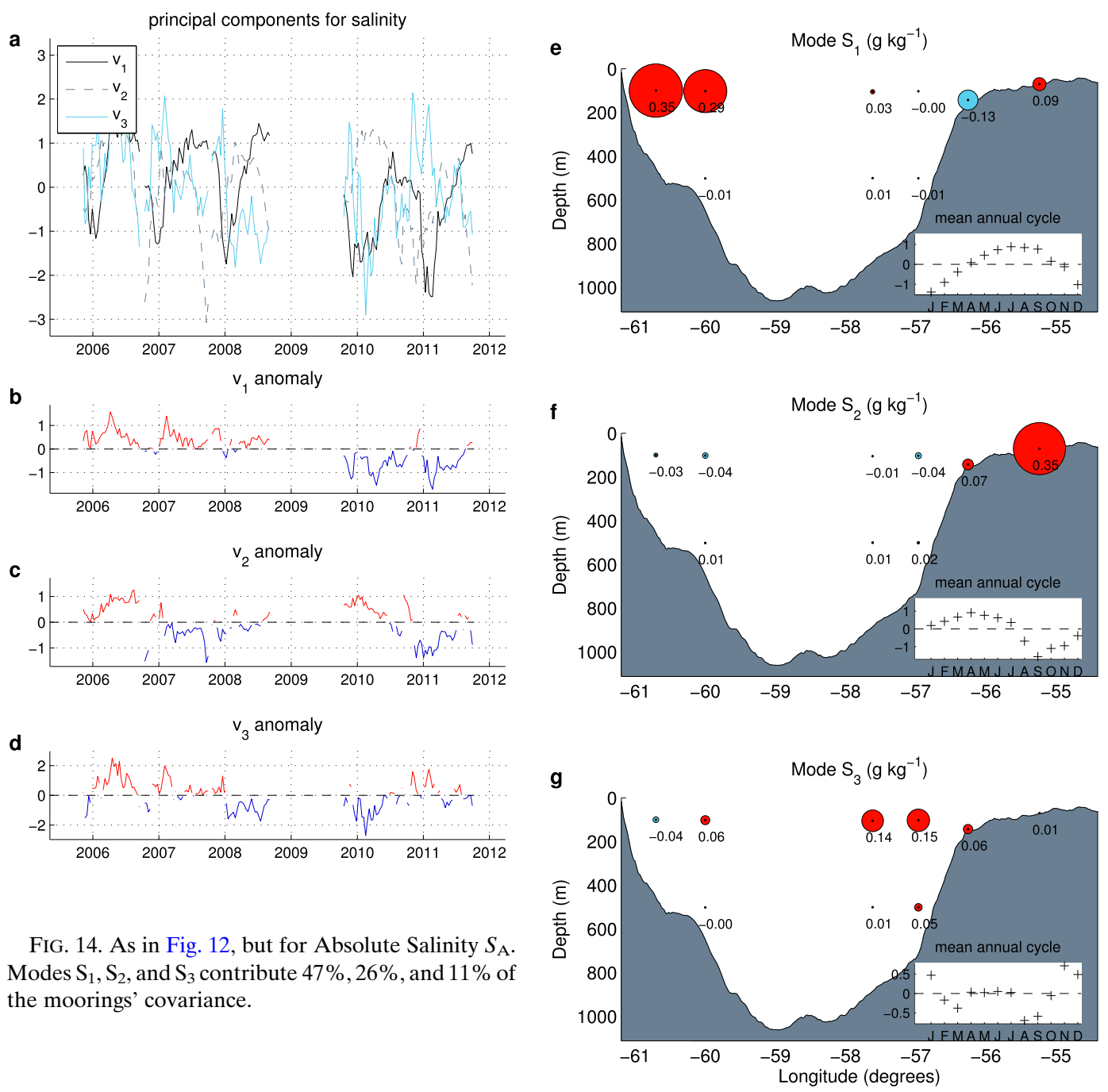

FIG. 14. As in Fig. 12, but for Absolute Salinity $S_{\mathrm{A}}$. Modes $S_{1}, S_{2}$, and $S_{3}$ contribute $47 \%, 26 \%$, and $11 \%$ of the moorings' covariance.

spring when exchange with the outer shelf resumes. In mid-September of 2010 (when isopycnals were still much shallower than they would become later in the winter), the Egedesminde Dyb Sill was clearly causing a severe depression of isotherms (and isopycnal) on the Disko Bay side relative to the outer trough side (Fig. 3f), indicating that the sill was already exercising topographic control on those isopycnals. The interaction between isopycnals and the Egedesminde Dyb Sill is captured in the schematic Fig. 15.

\section{2010 cool anomaly}

West Greenland Current waters in summer 2010 were actually unusually warm [first reported in Ribergaard (2011)], but the West Greenland Current transport in Davis Strait was weak in summer of 2010. We know that UpModIrmW, the waters that habitually enter Ilulissat Icefjord, shares isopycnals with BBTherW and that UpModIrmW and BBTherW intermingle in southern

Baffin Bay (Fig. 3). Also, BBTherW was detected at moorings on the Greenland shelf in 2010, and isopycnals across Baffin Bay were tilted upward toward Greenland in early 2010. We therefore argued that the immediate cause of the 2010 cool anomaly in Disko Bay was a greater than usual penetration of BBTherW water in early 2010. This hypothesis is consistent with Myers and Ribergaard (2013), who found that the coolness of near-surface waters in Disko Bay prior to the late 1990s was due to greater penetration of Baffin Bay waters. Andersen (1981) found that although pure Baffin Current waters were excluded from Disko Bay, the water entering Disko Bay prior to 1975 was a mixture of West Greenland Current waters and Baffin Current waters. Hansen et al. (2012) found that the shift from pre-1997 to post-1997 temperatures was accompanied by a shift in nutrient contents indicating a decreased fraction of Arctic-origin (i.e., BBArcW/BBTherW) water. 


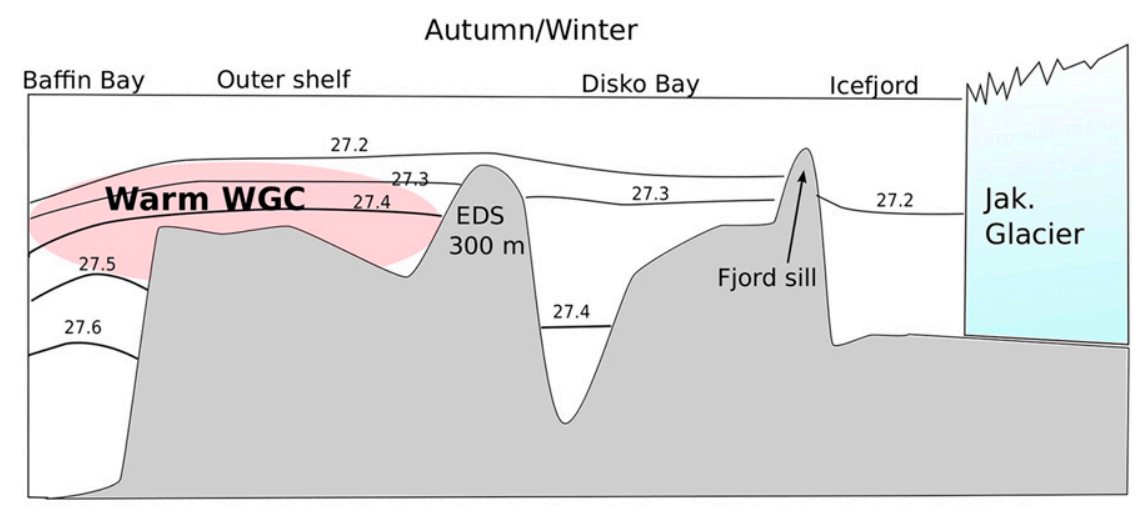

Spring/Summer

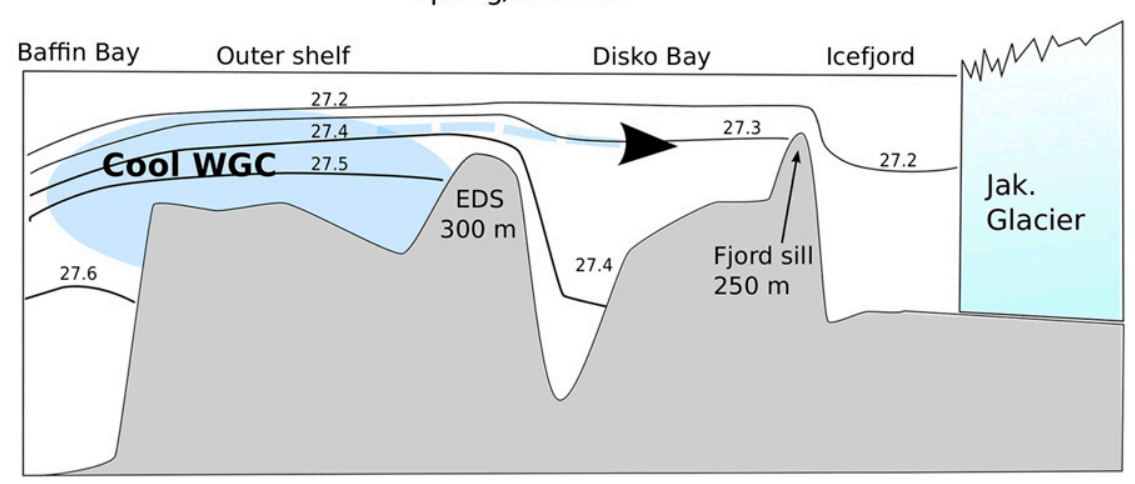

FIG. 15. Schematic diagram of seasonal exchange over the west Greenland continental shelf west of Ilulissat Icefjord. The warm phase of the WGC is masked by the EDS.

\section{a. NAO index}

Was the 2010 shift in the provenance of Disko Bay waters caused by surface atmospheric variability? The dominant pattern of sea level pressure anomalies in the Atlantic sector north of $20^{\circ} \mathrm{N}$ is called the North Atlantic Oscillation (NAO). This pattern emphasizes a low pressure center over Greenland and Iceland and high pressure west of Portugal at subtropical latitudes. Positive NAO index values imply low surface air pressure over Greenland and strong westerlies over the North Atlantic (Hurrell 1995).

The annually averaged NAO index for 2010 reached an all-time record low (supplemental information), and it is tempting to somehow attribute the 2010 shift to this isolated NAO anomaly. Indeed, Holland et al. (2008) attributed subsurface warming along west Greenland in the late 1990s to changes in the NAO. However, they found that the warming of subsurface waters along west Greenland occurred after the sharp drop in the NAO index in 1996 following a period of sustained positive phase in the early 1990s. Here, we observed a cooling of Ilulissat Icefjord waters in summer 2010 after the sharp drop in the NAO index in 2010. The resolution of this apparent contradiction is simply that there is a delay in the causal chain linking NAO index changes and subsurface temperatures on the west Greenland shelf.

A simple view of this causal chain as it was followed in the late 1990s is that negative NAO anomalies, corresponding to a weakened meridional pressure gradient, led to weakened westerlies over the North Atlantic, which in turn led to reduced winter cooling of the upper subpolar gyre. This relaxed the domed isopycnals of the gyre and therefore weakened its cyclonic circulation (Häkkinen and Rhines 2004). At the same time, the eastern limit of the weakened subpolar gyre moved westward such that, after a 1- or 2-yr delay (less delay in the rapid Irminger Current), more subtropical gyre waters entered the subpolar gyre and its boundary currents (Hátún et al. 2005; Bersch 2002). The decreased transport of the subpolar gyre was apparently less important than the warming of the gyre since about $1 \mathrm{yr}$ after the NAO shift of 1996, warmer waters mixed into the East/West Greenland Current began to arrive in Disko Bay (Holland et al. 2008). As shown in Table 1, it was in 1998 that the warming signal became fully expressed in Disko Bay. It is therefore more reasonable to explain the record Disko Bay/Ilulissat Icefjord temperatures of 2011 and 2012 by this advective pathway in connection with the strong negative NAO anomaly of 2010. 

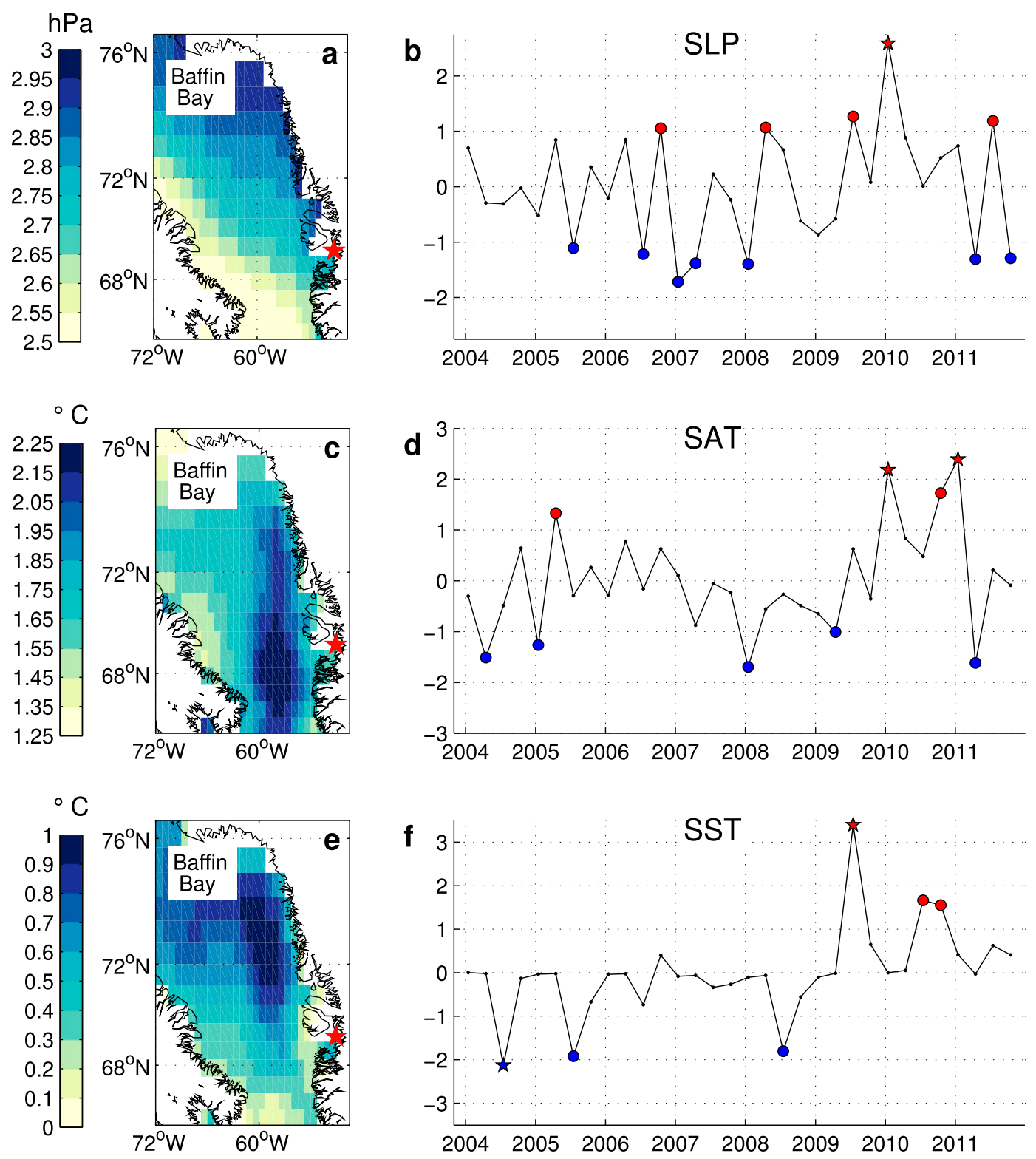

FIG. 16. ERA-Interim data for Baffin Bay region. Leading patterns of SLP, SAT, and SST anomalies and their seasonally averaged temporal variability from 2004 to 2011 in Baffin Bay are shown. Each variable $z$ was decomposed as $z=\phi_{1} v_{1}(t)+\phi_{2} v_{2}(t) \ldots$, where the spatial patterns $\phi_{k}$ were mutually orthogonal and the time-varying coefficients $v_{k}(t)$ were mutually orthogonal and had unit variance. Spatial patterns $\phi_{k}$ are mapped on the left and principal component time series $v_{k}(t)$ was mapped on the right in Figs. 16 to 19. (a) The leading mode of SLP anomalies accounts for $97 \%$ of variability. (b) The temporal expansion coefficient, normalized to have unit variance. Red (blue) dots highlight monthly anomalies greater (less) than one standard deviation. Red/blue stars show the same for two standard deviations. Anticorrelation of this pattern with the monthly NAO index is strong $(r=-0.62)$. High pressure in winter 2009/10 is consistent with the severe drop in NAO that began then. (c) The leading mode for SAT variability emphasizes heating over the middle of Baffin Bay and account for $87 \%$ of variability. (d),(f) Expansion coefficients for SAT and SST. (e) The leading mode for SST, emphasizing northern Baffin Bay, accounts for $74 \%$ of the total covariance.

\section{b. Baffin Bay atmospheric variability from ERA-Interim}

Looking next at more local atmospheric anomalies, we extracted 12-hourly sea level pressure (SLP), surface air temperature (SAT), sea surface temperature (SST), sea ice concentration (SIC), and wind stress fields over Baffin Bay from the ERA-Interim reanalysis product covering the period December 2003 to November 2011. 

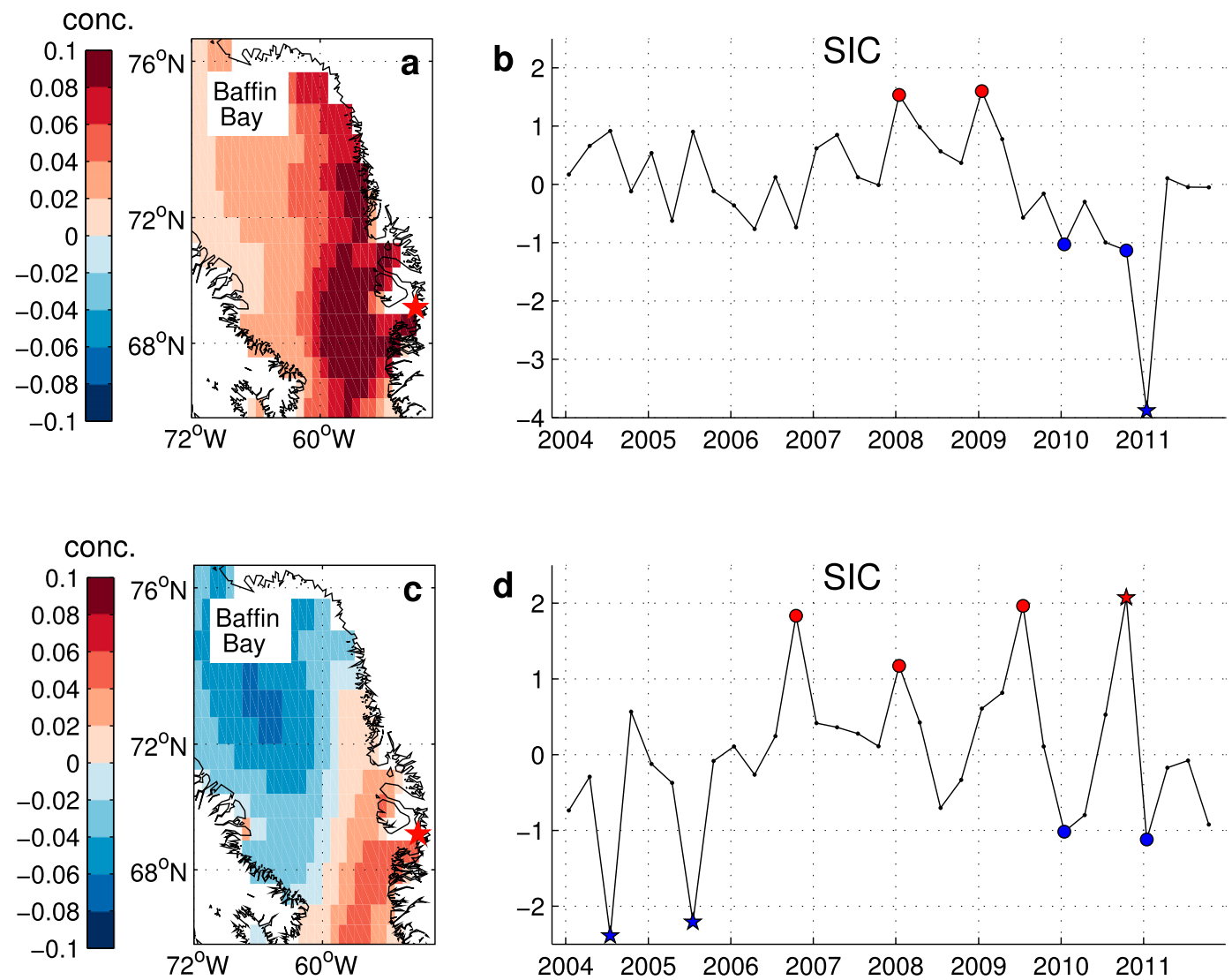

FIG. 17. Two leading patterns of SIC anomalies and their temporal variability from 2004 to 2011 in Baffin Bay. (a) The leading mode of SIC accounts for $46 \%$ of variability and emphasizes east-central Baffin Bay where the ice edge is found during the annual advance and retreat. (c) The second SIC mode, accounting for $18 \%$ of variability, emphasizes differences in SIC between central and southeast Baffin Bay. (b),(d) Temporal variability of first and second SIC modes. Dots and stars are as in Fig. 16.

The mean annual cycle was first removed and the remaining anomalies were then averaged over 3month intervals. A conventional EOF analysis was then performed on the seasonally averaged anomalies. For SLP, SAT, and SST, the leading empirical modes captured a large fraction of the covariability (Fig. 16). Sea ice variability was not as well captured by a single mode. The first two sea ice modes together accounted for $64 \%$ of the variability (Fig. 17). Finally, the leading modes of wind stress and the two leading modes of the wind stress curl are shown in Figs. 18 and 19.

Sea level pressure over all of Baffin Bay was anomalously high in winter 2009/10 (Fig. 16b), in agreement with the very low NAO index beginning then. Surface air temperatures over Davis Strait and southeast Baffin Bay in winter of 2009/10 were several degrees warmer than usual, but the same is true of winter 2010/11 (Figs. 16c,d), so no direct connection to the cool 2010 ocean anomaly is apparent. A more obvious link is the one between SAT, SST, and SIC. Summer sea surface temperatures in eastern Baffin Bay were high in 2009 and 2010, winter surface air temperatures were high in Davis Strait and southeast Baffin Bay in the following winters (2009/10 and 2010/11), while sea ice concentrations in south and southeast Baffin Bay were low those winters as well (Figs. 16, 17). We cannot justify asserting any dynamical connections-we simply point out that the conspicuous anomalies do not clearly distinguish 2010 from 2011.

Zonal wind stress anomalies tend to be coherent over most of Baffin Bay, while meridional anomalies concentrate in Davis Strait (Figs. 18a,c). Zonal stresses correlate with the NAO index $(r=0.38)$, and $2010 \mathrm{ex}$ hibited anomalous westward stresses that distinguished it from neighboring years. Meridional wind stress and firstmode wind stress curl anomalies are most intense over Davis Strait and have very similar temporal variability (Figs. 18d, 19b). For these variables, negative anomalies throughout 2009 are conspicuous. These anomalies would tend to induce upwelling along the Greenland shelf in Davis Strait. Positive density and salinity 

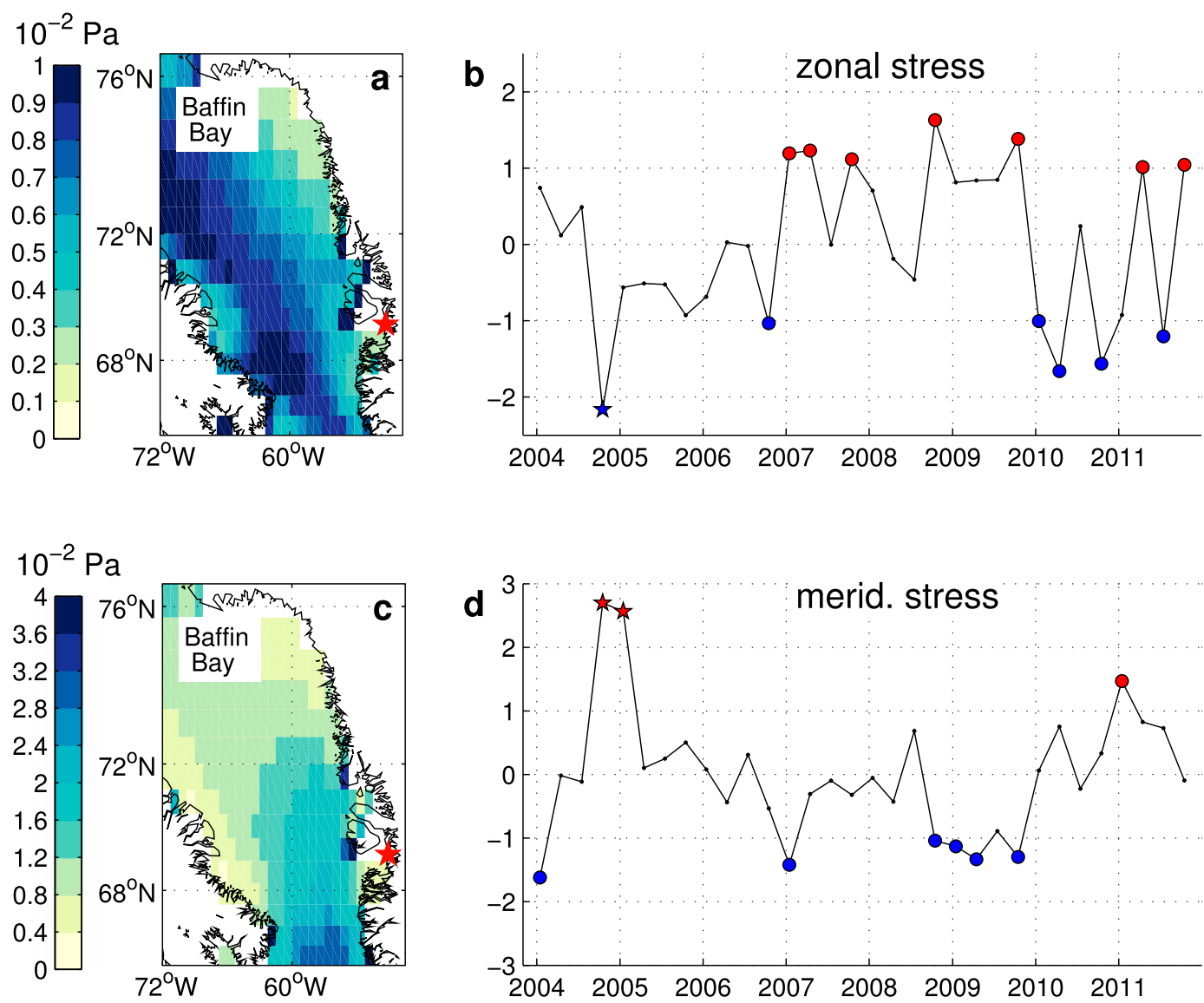

FIG. 18. Leading patterns of zonal wind stress $\tau_{x z}$ and meridional wind stress $\tau_{y z}$. (a) The leading mode for $\tau_{x z}$ accounts for $51 \%$ of the variability and captures the broadly uniform stress from westerlies off the Canadian Arctic. (c) The leading mode for $\tau_{y z}$ accounts for $71 \%$ of the variability and emphasizes meridional stress in Davis Strait. (b),(d) Temporal expansion coefficients are as in Fig. 16. Temporal correlations of these modes with the NAO index are $r=0.38$ (zonal stress) and $r=0.09$ (meridional stress).

anomalies were indeed observed in the shallow shelf moorings in the second half of 2009 (not shown). This perhaps preconditioned the region for the positive density anomalies that dominated the Greenland shelf in early 2010 (Fig. 13b), but it is not apparent how Ekman upwelling in 2009 could directly cause the cool anomaly of 2010.

Of all the mechanical wind variables and thermodynamic variables, only the zonal stress (and associated upwelling/downwelling) anomaly of 2010 over Baffin Bay suggests any direct relation to the cool 2010 ocean anomaly. These zonal stress anomalies are conceivably related to the changes in potential vorticity that Myers and Ribergaard (2013) found were linked to the late 1990s change in circulation in southern Baffin Bay, but this is a question for future research. Alternatively, the zonal stress anomalies might simply reflect the hemispheric wind patterns associated with the low NAO index in 2010, bearing no direct connection to the ocean temperature anomaly in 2010 in Disko Bay and Ilulissat Icefjord.

\section{c. Salinity anomaly from the Arctic Ocean}

Rather than being linked to North Atlantic or Baffin Bay meteorology, a final possibility is that the cool 2010 ocean anomaly was linked to the Arctic Ocean via the Canadian Arctic Archipelago. Seeking an explanation for the changes in polar waters in Disko Bay and on the Greenland shelf near Disko Bay, Myers and Ribergaard (2013) suggested that changes in southeast Baffin Bay might be linked to Arctic processes via the connection between sea surface gradients across Baffin Bay, gradients across the Canadian Arctic Archipelago, and flux through the archipelago.

Curry et al. (2014) pointed out that the low salinity of the Baffin Current from late 2009 to late 2010 was due to a large influx of liquid freshwater through the Canadian Arctic. This fresh signal is captured in their Fig. 4 (Arctic Water salinity) and is visible in our Fig. 14b. The freshwater was released from the Beaufort Gyre after a shift in wind stress over the Arctic Ocean in 2009 

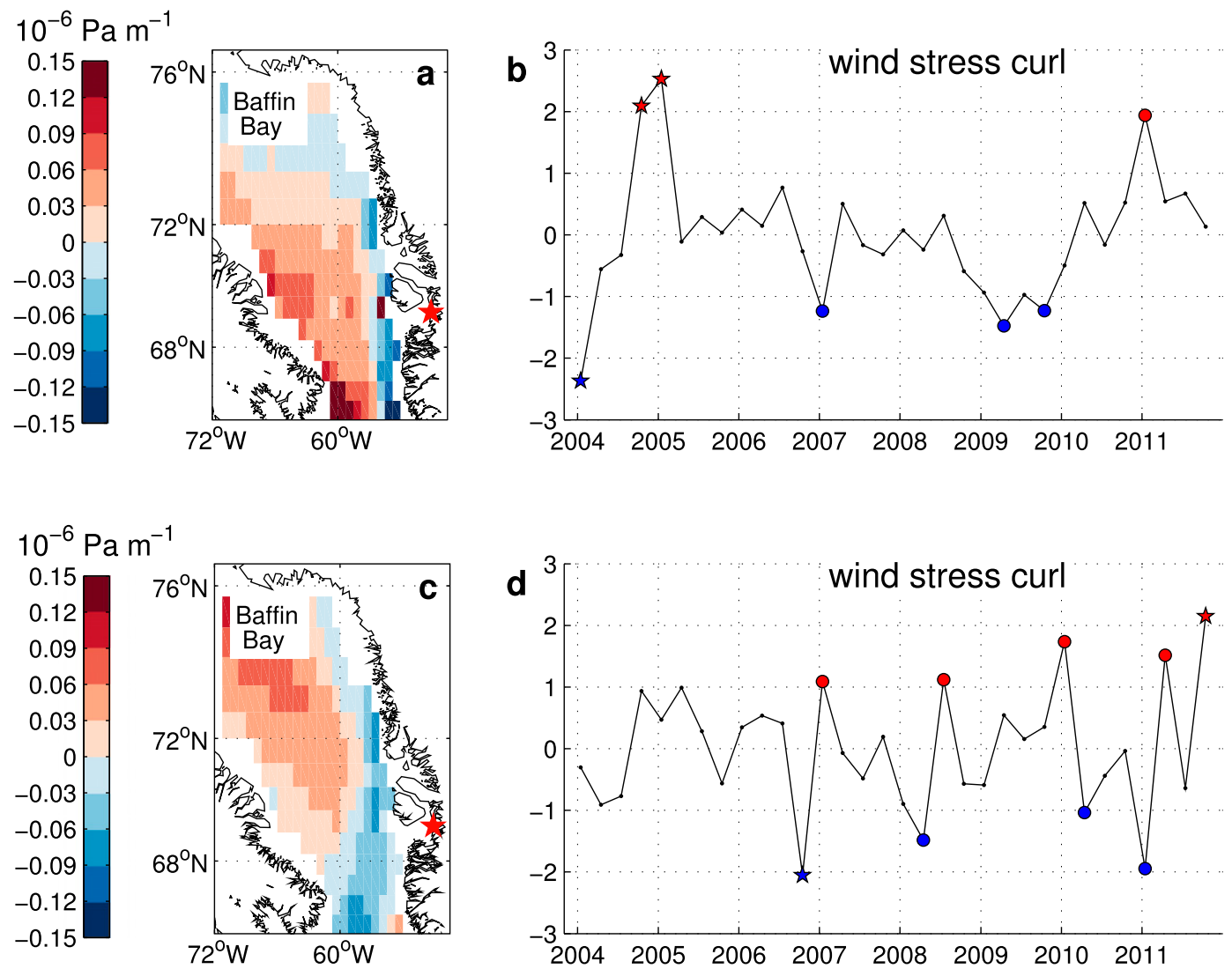

FIG. 19. (a) The leading mode for wind stress curl accounts for $37 \%$ of the variability and is primarily associated with gradients in meridional stress across Davis Strait. When the coefficient for this pattern is positive, Ekman transport induces downwelling on the Greenland side of Davis Strait and upwelling on the Baffin Island side. (c) The second-mode accounts for $24 \%$ of the variability and has temporal variability similar to the leading zonal stress pattern, with upwelling and downwelling varying along the principal (north-south) axis of Baffin Bay. (b),(d) Temporal expansion coefficient are as in Fig. 16.

(Timmermans et al. 2011). In early 2010, there was also a positive salinity anomaly over the west Greenland shelf in Davis Strait (Fig. 14c), possibly due to the upwelling induced by anomalous meridional wind stresses in the later part of 2009. Together with the freshening of the Baffin Current, this caused the isopycnals across Baffin Bay to tilt upward toward west Greenland more than usual in early 2010 (Fig. 13b).

In January and February 2010, the West Greenland Current was nearly stagnant in eastern Davis Strait, and the core of the Baffin Current had shifted east to the center of Baffin Bay (Fig. 11), both in accordance with upwardsloping isopycnals across Baffin Bay. The eastward shift of the Baffin Current would also shift the thermocline to the east, bringing BBTherW into contact with mooring WG1151, for instance (Fig. 4). It was in May 2010 that eastern Disko Bay probably cooled to temperatures last observed in the 1980s (Gladish et al. 2015).

The fresh anomaly in the Baffin Current was also present in 2011 (Fig. 14b), but isopycnals across Baffin
Bay were domed in 2011 rather than tilted, in part because of the extremely warm and fresh waters on the west Greenland shelf (Fig. 12c). Those fresh shelf waters possibly represented the delayed arrival of the 2009/10 Arctic freshwater pulse after having traveled all the way around Greenland in the East/West Greenland Current. Because of the domed isopycnals, the Baffin Current was confined to the west and the West Greenland Current transport remained strongly northward in early 2011 [Fig. 11; December-February (DJF) 2010/11], so cold Baffin Current waters did not gain access to the west Greenland shelf.

\section{Summary and conclusions \\ a. Climatological aspects}

Our first major finding is that Ilulissat Icefjord basin waters, which make up the greater part of the thermal boundary condition for Jakobshavn Glacier, are in general a nearly equal mixture of Irminger Current waters 
and low-salinity polar waters. Along the west Greenland coast in summer, Upper Modified Irminger Waters (UpModIrmW; Table 2) destined for Ilulissat Icefjord are typically found within a density and temperature front formed between modified Irminger Current water over the west Greenland slope and polar waters over the west Greenland shelf/slope. The warmest waters of the West Greenland Current are prevented from entering Ilulissat Icefjord by bathymetric impediments between the west Greenland shelf break and Ilulissat Icefjord, namely, the Egedesminde Dyb Sill and the Iceberg Bank at the fjord mouth.

Our second major finding is that there are huge seasonal cycles in density and temperature of UpModIrmW along west Greenland and yet there is, comparatively, almost no seasonal cycle at the seafloor just west of Ilulissat Icefjord (at 350-m depth, mean $\sigma_{\theta}=27.32$ ) or inside Ilulissat Icefjord basin (Gladish et al. 2015). The available evidence suggests that the annual cycle of vertical isopycnal migration over the outer shelf conspires with the Egedesminde Dyb Sill to mask out the warm phase of the UpModIrmW temperature cycle, leaving Disko Bay/Ilulissat Icefjord relatively constant each year beneath an upper layer that may experience large seasonal variations. Exchange over the Egedesminde Dyb Sill probably occurs in spring (or earlier) each year.

The fact that Ilulissat Icefjord basin water generally contains a large fraction of low-salinity polar waters and the fact that there is a large annual cycle of temperatures along the west Greenland shelf/slope necessitates a refinement of the schema implied by Holland et al. (2008), in which a northward-propagating pulse of warm West Greenland Current waters suddenly reached Disko Bay/ Ilulissat Icefjord in 1997 . First, water of nearly $3^{\circ} \mathrm{C}$ in the Ilulissat Icefjord basin density class did reach Disko Bay in 1997 , but water warmer than $4^{\circ} \mathrm{C}$ in that density class reached at least to Davis Strait every year since 1990, in autumn. Second, the averaging down to $600-\mathrm{m}$ depths in Fig. 4 of Holland et al. (2008) obscures the fact that the warmest West Greenland Current waters never reached Ilulissat Icefjord. Third, Ilulissat Icefjord water temperatures are influenced as much by temperature variability of low-salinity polar waters (see also Myers and Ribergaard 2013) as by variability of the temperature maximum of the Irminger Current waters entering the West Greenland Current at Cape Farewell.

\section{b. Interannual variability}

The Irminger Current is the single source of warm and saline waters in west Greenland. There are, however, two potential sources of low-salinity polar waters: the Baffin Current and the East/West Greenland Current, which tend to be warmer than the Baffin Current at the same density
(Tang et al. 2004; Myers et al. 2009). East Greenland Current polar waters north of Denmark Strait on the Greenland shelf are cold (Rudels et al. 2002), but by the time they reach west Greenland they are generally above $0^{\circ} \mathrm{C}$ in summer and autumn when measurements are available (Myers et al. 2009). They are sometimes as warm as $2^{\circ} \mathrm{C}$ in summer and $6^{\circ} \mathrm{C}$ in autumn at $\sigma_{\theta}=27.0$. (Less dense polar waters can be considerably warmer still but are not part of the mixing line containing fjord basin waters.) Temperature variability in East/West Greenland Current polar waters therefore impacts the thermal boundary conditions of Jakobshavn Glacier. ${ }^{4}$ However, as Myers and Ribergaard (2013) proposed to explain the warming of Disko Bay polar waters around 1997, a shift in the fraction of West Greenland Current polar waters compared to Baffin Current polar waters entering Disko Bay would also bring about major temperature changes, impacting not just the above-sill waters in Ilulissat Icefjord but also the basin waters.

Temperatures in Disko Bay/Ilulissat Icefjord have not remained uniformly high since their steplike change in the late 1990s that triggered the massive response of Jakobshavn Glacier. From 2008 to 2013, Disko Bay/ Ilulissat Icefjord waters were as warm as they likely were in 1998 and 1999, except in 2010 when Ilulissat Icefjord was in a cooler mode, which has occurred at various times since at least the 1980s. In 2000/01 and 2004-07, Disko Bay/Ilulissat Icefjord basin temperatures were likely in a cool to moderate state.

The huge seasonal temperature cycle on UpModIrmW isopycnals in the West Greenland Current is never adequately sampled by CTD profiles and likely is aliased in the variability of the quasi-annual CTD surveys. The temperature minimum of this cycle must occur early each year; the fact that CTD surveys off southwest Greenland take place in midsummer means they do not observe this minimum. It is therefore impossible to confidently isolate the cold seasonal signal due to the West Greenland Current from the steadier cold signal of the Baffin Current in order to attribute cool Disko Bay/Ilulissat Icefjord years to a shift in provenance

\footnotetext{
${ }^{4}$ It is ambiguous whether a typical East/West Greenland Current polar water parcel maintains a relatively constant salinity during its journey around Greenland, being warmed by surface fluxes, or whether West Greenland Current polar water parcels are actually the product of mixing between very cold and very low-salinity PSW and pure Irminger Current waters where they meet south of Denmark Strait. In the first case, the fjord basin temperature could be sensitive to changes in summer air-sea heat fluxes in the Greenland boundary currents, and in the second case it would be more sensitive to changes in mixing at the density front between the East Greenland Current and Irminger Current.
} 
rather than to interannual variability within the West Greenland Current. (The Davis Strait moorings over the Greenland shelf/slope sample all year, but these moorings are possibly heavily influenced by the Baffin Current, so the ambiguity remains.)

Keeping in mind the limitation of our dataset in the face of these natural modes of variability, we used summer CTD data between Cape Farewell and Disko Bay to obtain our third major result: a categorization of all summers into three categories. First, in some summers, Disko Bay in the fjord basin density range was essentially the same as in the West Greenland Current. ${ }^{5}$ In these years, whether Jakobshavn Glacier was in contact with $\mathrm{WFjW}, \mathrm{CFjW}$, or something in between was mainly determined by temperature shifts of the mixing line joining Irminger Current waters and low-salinity waters on the Greenland shelf. Second, in some years, Disko Bay was cooler than equally dense West Greenland Current waters by $0.5^{\circ}-1.0^{\circ} \mathrm{C} .^{6}$ At least in 2010 , when there was good mooring coverage in Davis Strait, there is strong evidence that the provenance of Disko Bay changed (partially) to the cooler Baffin Current. Third, in summer of 2009, Disko Bay was significantly warmer than West Greenland Current waters. This may have been because of a delayed arrival of West Greenland Current waters because of unusually low-density waters on the west Greenland slope pushing the critical $\sigma_{\theta}=27.3$ isopycnal below the depth of the Egedesminde Dyb Sill in early 2009. In the remaining years, agreement was ambiguous or data were insufficient to classify. ${ }^{7}$

The dynamics that control the degree to which Baffin Current waters spread over the west Greenland shelf are unknown. Myers and Ribergaard (2013) point out that potential vorticity contours tended to cross Davis Strait more post-1997 than pre-1997. Since potential vorticity is constant along streamlines (in the absence of diabatic fluxes and friction), this shows that, post-1997, Baffin Current waters were more likely to flow south over Davis Strait rather than to be deflected and flow toward the mouth of Egedesminde Dyb, following bathymetric contours to avoid vertical stretching. This does not, however, explain why less deflection occurred post-1997.

\section{c. 2010 anomaly}

We cannot entirely rule out meteorological forcing over Baffin Bay in winter of 2009/10 as the cause of the cool fjord anomaly of summer 2010. It is conceivable, for instance, that reduced sea ice over the west Greenland

\footnotetext{
${ }^{5} 1990,1998,2000,2002,2006,2007$, and 2008.

${ }^{6} 1996,2003,2004$, and 2010.

${ }^{7} 1991-95,1997,2005$, and 2011.
}

shelf between Davis Strait and Disko Bay along with a weak West Greenland Current led to either anomalous cooling of West Greenland Current waters entering Disko Bay or, somehow, the penetration of Baffin Current waters onto the west Greenland shelf.

It appears more likely, however, that a freshwater pulse from the Canadian Arctic into the Baffin Current in late 2009 to 2010 was responsible for the cool 2010 fjord waters. The fresh anomaly in the upper $250 \mathrm{~m}$ of western and central Davis Strait appears to have shifted the Baffin Current eastward in early 2010, bringing cool BBTherW close enough to the west Greenland shelf to mix with West Greenland Current waters and producing CFjW that flowed toward Disko Bay. The freshwater pulse from the Beaufort Gyre that freshened the Baffin Current in 2010 could, we suggest, also have caused the low-salinity anomaly in the West Greenland Current in early 2011 (Fig. 4), delayed because of the longer journey around Greenland. This would be an independent pathway by which wind stress changes over the Arctic Ocean can affect variability of Ilulissat Icefjord waters.

Shifts in the NAO index have been associated with shifts in Disko Bay/Ilulissat Icefjord temperatures (Holland et al. 2008). The cool Disko Bay/Ilulissat Icefjord anomaly of 2010, however, cannot be attributed to the isolated negative NAO index anomaly in 2010. If the NAO shift of the 1990s can be used as a guide for estimating the advective delay, the low NAO index of 2010 is more likely responsible for the record warm waters we found in Ilulissat Icefjord in 2011 and 2012.

The oceanic boundary condition for Jakobshavn Glacier is a product of the interplay of two boundary currents (the Baffin Current and East Greenland/West Greenland/Irminger Current system) and complex bathymetry; it is potentially sensitive to atmospheric forcing from the Arctic Ocean and the North Atlantic. Given the large seasonal variability observed in Davis Strait, the greatest mystery is that the variability of thermal forcing at Jakobshavn Glacier was not greater than it has been. To gain predictive skill for interannual ocean thermal forcing at Jakobshavn Glacier, it will be necessary for models to have an adequate representation of the inputs to the Greenland boundary currents and the Baffin Current, correct representations of mixing across the sharp fronts associated with these currents, and a correct representation of the dynamics of the seasonally varying and topographically controlled flow across the west Greenland shelf into Disko Bay.

Acknowledgments. NYU observations at Ilulissat were supported by NSF Office of Polar Program Grants ARC-0806393 and ARC-1304137, NASA Polar Programs 
Grant NNX08AN52G, and NYU Abu Dhabi Center for Global Sea Level Change Grant G1204.

\section{APPENDIX}

\section{Quality Control for Davis Strait moorings}

For each year-long mooring time series, the following procedure was iterated up to five times. First, using the samples with $\left|S_{\mathrm{A}}-\overline{S_{\mathrm{A}}}\right|$ less than the 71st percentile, we fit a quadratic $T_{1}\left(S_{\mathrm{A}}\right)$ to those temperatures and salinities. Next, using the best-fitting $71 \%$ of those samples, we obtained a new best fit curve $T_{2}\left(S_{\mathrm{A}}\right)$. The function $T_{2}$ captures how the "central half" of the full time series clusters in $T-S_{\mathrm{A}}$ space. Then residuals for all the samples were found and those samples with $\left|T-T_{2}\left(S_{\mathrm{A}}\right)\right|$ larger than the 99.9th percentile were automatically removed, along with samples with $\left|S_{\mathrm{A}}-\overline{S_{\mathrm{A}}}\right|$ larger than the 99.9th percentile. To detect more subtle outliers, we constructed the percentile function $p(f)$ equal to the residual $\left|T-T_{2}\left(S_{\mathrm{A}}\right)\right|$ below which the fraction $f$ of samples are found. The term $p(f)$ is generally nearly linear for $f<0.5$ but grows rapidly for $f$ close to 1.0 when there are extreme outliers. Fitting a line to $p(f)$ for $0 \leq f \leq 0.5$ and evaluating this line for $f=0.99$, we obtain a value $p_{99}$. When $p(0.99)>4 \times p_{99}$, we interpret this as saying that there is a cluster of at least $1 \%$ of data points that are outliers. All samples with $\left|T-T_{2}\left(S_{\mathrm{A}}\right)\right|>4 \times p_{99}$ were therefore removed and the procedure was repeated. Otherwise the procedure terminated. This procedure removed very few points in moorings with high variability but removed questionable segments for deeper moorings with an otherwise tight $T-S_{\mathrm{A}}$ relationship. These segments may correspond to times when the conductivity cell was contaminated, for instance.

\section{REFERENCES}

Andersen, O., 1981: The annual cycle of temperature, salinity, currents and water masses in Disko Bugt and adjacent waters, west Greenland. Medd. Groenl. Biosci., 5, 3-33.

Bacon, S., G. Reverdin, I. Rigor, and H. Snaith, 2002: A freshwater jet on the east Greenland shelf. J. Geophys. Res., 107, doi:10.1029/2001JC000935.

Bersch, M., 2002: North Atlantic Oscillation-induced changes of the upper layer circulation in the northern North Atlantic Ocean. J. Geophys. Res., 107, 3156, doi:10.1029/2001JC000901.

Cuny, J., P. Rhines, P. Niiler, and S. Bacon, 2002: Labrador Sea boundary currents and the fate of the Irminger Sea Water. J. Phys. Oceanogr., 32, 627-647, doi:10.1175/1520-0485(2002)032<0627: LSBCAT $>2.0 . \mathrm{CO} ; 2$.

- - - , and R. Kwok, 2005: Davis Strait volume, freshwater and heat fluxes. Deep-Sea Res., 52, 519-542, doi:10.1016/ j.dsr.2004.10.006.

Curry, B., C. M. Lee, and B. Petrie, 2011: Volume, freshwater, and heat fluxes through Davis Strait, 2004-05. J. Phys. Oceanogr., 41, 429-436, doi:10.1175/2010JPO4536.1.
, R. Moritz, and R. Kwok, 2014: Multiyear volume, liquid freshwater, and sea ice transports through Davis Strait, 2004-10. J. Phys. Oceanogr., 44, 1244-1266, doi:10.1175/ JPO-D-13-0177.1.

Dee, and Coauthors, 2011: The ERA-Interim reanalysis: Configuration and performance of the data assimilation system Quart. J. Roy. Meteor. Soc., 137, 553-597, doi:10.1002/qj.828.

Gladish, C., D. Holland, A. Rosing-Asvid, J. Behrens, and J. Boje, 2015: Oceanic boundary conditions for Jakobshavn Glacier. Part I: Variability and renewal of Ilulissat Icefjord waters, 2001-14. J. Phys. Oceanogr., 45, 3-32, doi:10.1175/ JPO-D-14-0044.1.

Häkkinen, S., and P. Rhines, 2004: Decline of subpolar North Atlantic circulation during the 1990's. Science, 304, 555-559, doi:10.1126/science.1094917.

Hansen, M., T. Nielsen, C. Stedmon, and P. Munk, 2012: Oceanographic regime shift during 1997 in Disko Bay, western Greenland. Limnol. Oceanogr., 57, 634-644, doi:10.4319/ lo.2012.57.2.0634.

Hátún, H., A. Sandø, H. Drange, B. Hansen, and H. Valdimarsson, 2005: Influence of the Atlantic Subpolar Gyre on the thermohaline circulation. Science, 309, 1841-1844, doi:10.1126/ science. 1114777 .

Holland, D., R. Thomas, B. D. Young, M. Ribergaard, and B. Lyberth, 2008: Acceleration of Jakobshavn Isbræ triggered by warm subsurface ocean waters. Nat. Geosci., 1, 659-664, doi:10.1038/ngeo316.

Howat, I., I. Joughin, S. Tulaczyk, and S. Gogineni, 2005: Rapid retreat and acceleration of Helheim Glacier, east Greenland. Geophys. Res. Lett., 32, L22502, doi:10.1029/2005GL024737.

- Y. Y. Ahn, I. Joughin, M. van den Broeke, J. Lenaerts, and B. Smith, 2011: Mass balance of Greenland's three largest outlet glaciers, 2000-2010. Geophys. Res. Lett., 38, L12501, doi:10.1029/2011GL047565.

Hurrell, J., 1995: Decadal trends in the North Atlantic Oscillation: Regional temperatures and precipitation. Science, 269, 676679, doi:10.1126/science.269.5224.676.

IOC, SCOR, and IAPSO, 2010: The International Thermodynamic Equation of Seawater-2010: Calculation and use of thermodynamic properties. Intergovernmental Oceanographic Commission, Manuals and Guides 56, 220 pp. [Available online at http://www.teos-10.org/pubs/TEOS-10_Manual.pdf.]

Jakobsson, M., and Coauthors, 2012: The International Bathymetric Chart of the Arctic Ocean (IBCAO) version 3. Geophys. Res. Lett., 39, L12609, doi:10.1029/2012GL052219.

Joughin, I., W. Abdalati, and M. Fahnestock, 2004: Large fluctuations in speed on Greenland's Jakobshavn Isbræ glacier. $\mathrm{Na}$ ture, 432, 608-610, doi:10.1038/nature03130.

- R. Alley, and D. Holland, 2012: Ice-sheet response to oceanic forcing. Science, 338, 1172-1176, doi:10.1126/science.1226481.

Krabill, W., and Coauthors, 2004: Greenland Ice Sheet: Increased coastal thinning. Geophys. Res. Lett., 31, L24402, doi:10.1029/ 2004GL021533.

Lindsay, R., M. Wenshahan, A. Schweiger, and J. Zhang, 2014: Evaluation of seven different atmospheric reanalysis products in the Arctic. J. Climate, 27, 2588-2606, doi:10.1175/ JCLI-D-13-00014.1.

Lloyd, J., M. Moros, K. Perner, R. Telford, A. Kuijpers, E. Jansen, and D. McCarthy, 2011: A $100 \mathrm{yr}$ record of ocean temperature control on the stability of Jakobshavn Isbræ, west Greenland. Geology, 39, 867-870, doi:10.1130/G32076.1.

Motyka, R., M. Truffer, M. Fahnestock, J. Mortensen, S. Rysgaard, and I. Howat, 2011: Submarine melting of the 1985 
Jakobshavn Isbræ floating tongue and the triggering of the current retreat. J. Geophys. Res., 116, F01007, doi:10.1029/ 2009JF001632.

Myers, P., and M. Ribergaard, 2013: Warming of the Polar Water layer in Disko Bay and potential impact on Jakobshavn Isbræ. J. Phys. Oceanogr., 43, 2629-2640, doi:10.1175/ JPO-D-12-051.1.

_- N. Kulan, and M. Ribergaard, 2007: Irminger Water variability in the West Greenland Current. Geophys. Res. Lett., 34, L17601, doi:10.1029/2007GL030419.

— C. Donnelly, and M. Ribergaard, 2009: Structure and variability of the West Greenland Current in summer derived from 6 repeat standard sections. Prog. Oceanogr., 80, 93-112, doi:10.1016/j.pocean.2008.12.003.

Pickart, R., D. Torres, and P. Frantantoni, 2005: The East Greenland Spill Jet. J. Phys. Oceanogr., 35, 1037-1053, doi:10.1175/ JPO2734.1.

Renfrew, I., G. Moore, P. Guest, and K. Bumke, 2002: A comparison of surface layer and surface turbulent flux observations over the Labrador Sea with ECMWF analysis and NCEP reanalyses. J. Phys. Oceanogr., 32, 383-400, doi:10.1175/ 1520-0485(2002)032<0383:ACOSLA > 2.0.CO;2.

Ribergaard, M., 2011: Oceanographic investigations off west Greenland 2010. NAFO Scientific Council Documents Tech. Rep., 44 pp. [Available online at http://ocean.dmi.dk/staff/ mhri/Docs/scr11-001.pdf.]

_ 2013: Oceanographic investigations off west Greenland 2012. NAFO Scientific Council Documents Tech. Rep. 13/003, 50 pp. [Available online at http://ocean.dmi.dk/staff/mhri/Docs/ scr13-003.pdf.]

Rignot, E., and P. Kanagaratnam, 2006: Changes in the velocity structure of the Greenland Ice Sheet. Science, 311, 986-990, doi:10.1126/science. 112138 .

_ I. Fenty, D. Menemenlis, and Y. Xu, 2012: Spreading of warm ocean waters around Greenland as a possible cause for glacier acceleration. Ann. Glaciol., 53 (60), 257-266, doi:10.3189/ 2012AoG60A136.

Rudels, B., E. Fahrbach, J. Meincke, G. Budéus, and P. Eriksson, 2002: The East Greenland Current and its contribution to the Denmark Strait overflow. J. Mar. Sci., 59, 1133-1154, doi:10.1006/jmsc.2002.1284.
Schumann, K., D. Völker, and W. Weinrebe, 2012: Acoustic mapping of the Ilulissat Ice Fjord mouth, west Greenland. Quat. Sci. Rev., 40, 78-88, doi:10.1016/j.quascirev.2012.02.016.

Seale, A., P. Christoffersen, R. Mugford, and M. O'Leary, 2011: Ocean forcing of the Greenland Ice Sheet: Calving fronts and patterns of retreat identified by automatic satellite monitoring of eastern outlet glaciers. J. Geophys. Res., 116, F03013, doi:10.1029/2010JF001847.

Straneo, F., and P. Heimbach, 2013: North Atlantic warming and the retreat of Greenland's outlet glaciers. Nature, 504, 36-43, doi:10.1038/nature12854.

— and Coauthors, 2012: Characteristics of ocean waters reaching Greenland's glaciers. Ann. Glaciol., 53 (60), 202-210, doi:10.3189/2012AoG60A059.

Sutherland, D., and R. Pickart, 2008: The East Greenland Coastal Current: Structure, variability, and forcing. Prog. Oceanogr., 78, 58-77, doi:10.1016/j.pocean.2007.09.006.

Tang, C., C. Ross, T. Yao, B. Petrie, B. DeTracey, and E. Dunlap, 2004: The circulation, water masses and sea-ice of Baffin Bay. Prog. Oceanogr., 63,183-228, doi:10.1016/j.pocean.2004.09.005.

Thomas, R., 2004: Force-perturbation analysis of recent thinning and acceleration of Jakobshavn Isbræ, Greenland. J. Glaciol., 50 (168), 57-66, doi:10.3189/172756504781830321.

_ - and Coauthors, 2000: Substantial thinning of a major east Greenland outlet glacier. Geophys. Res. Lett., 27, 1291-1294, doi:10.1029/1999GL008473.

— W. Abdalati, E. Frederick, W. Krabill, S. Manizade, and K. Steffen, 2003: Investigation of surface melting and dynamic thinning on Jakobshavn Isbræ, Greenland. J. Glaciol., 49 (165), 231-239, doi:10.3189/172756503781830764.

Timmermans, M.-L., A. Proshutinsky, R. Krishfield, D. K. Perovich, J. A. Richter-Menge, T. P. Stanton, and J. M. Toole, 2011: Surface freshening in the Arctic Ocean's Eurasian basin: An apparent consequence of recent change in the wind-driven circulation. J. Geophys. Res., 116, C00D03, doi:10.1029/2011JC006975.

Våge, K., and Coauthors, 2011: The Irminger Gyre: Circulation, convection, and interannual variability. Deep-Sea Res., 58, 590-614, doi:10.1016/j.dsr.2011.03.001.

Whitehead, J., 1998: Topographic control of oceanic flows in deep passages and straits. Rev. Geophys., 36, 423-440, doi:10.1029/ 98RG01014. 